九州大学学術情報リポジトリ

Kyushu University Institutional Repository

\title{
Taxonomic study on the Tenebrionidae (Coleoptera) of the Ryukyu Islands
}

Chujo, Michitaka

Entomological Laboratory, Department of Agriculture, Kyushu University

https://doi.org/10.5109/22745

出版情報：九州大学大学院農学研究院紀要. 14 (1)，pp.1-32，1966-06. Kyushu University バージョン：

権利関係: 
Journal of the Faculty of Agriculture, Kyushu University, Vol. 14, No. 1 June 30,1966

Taxonomic study on the Tenebrionidae (Coleoptera) of the Ryukyu Islands ${ }^{1}$

\section{Michitaka CHÛjô ${ }^{2}$}

\section{PREFACE}

Up to the present, numerous species of the Tenebrionidae of the Ryukyu Islands have been reported fragmentarily, but in the lack of abundant materials, even an enumeration of the species has been virtually impossible.

Fortunately, however, the members of the Kyushu University Expeditions to the Yaeyama Group and the teams of entomologists sent to the Ryukyu Islands by the Japan-U. S. Binational Cooperative Science Program have made particular efforts during the summers and autumn of 1962,1963 and 1964 to collect materials of the Tenebrionidae which have been of great assistance in the preparation of this paper. In addition, I was extremely fortunate in having at my disposal materials preserved in the collections of Kyushu University and B. P. Bishop Museum and in the private collection of Mr. T. Shibata.

This paper is the result of a taxonomic study on the Tenebrionidae of the Ryukyu Islands. The object of this work has been to compile and revise previous knowledge concerning the family of the islands and to present additional information made available by the present study.

Before going further I express my cordial thanks to Prof. K. Yasumatsu, Prof. S. Miyamoto, Prof. T. Shirôzu, Dr. K. Yano and Mr. T. Saigusa of Kyushu University for their continual kind guidance, I also express my sincere thanks to Dr. J. L. Gressitt of B. P. Bishop Museum and Mr. Shibata for the loan of specimens and for making facilities available to study some of the type specimens.

1 Contribution Ser. 2, No. 241, Entomological Laboratory, Kyushu University.

2 Entomological Laboratory, Faculty of Agriculture, Kyushu University. 


\section{Historical REVIEW OF THE STUDIES OF THE TENEBRIONIDAE OF THE RYUKYU ISLANDS}

The outset of taxonomic and zoogeographic study on the tenebrionid beetles of the Ryukyu Islands was not so old. Actually the first record of the tenebrionid species was done in the last decade of the 18th century, and since then several studies had been intermittently reported. But in each report a few species were merely recorded with other beetles belonging to different families. The following is the historical account of the studies.

1. 1896. In his paper on the Coleopterous fauna of Japan, G. Lewis described on new species, Plesiophthalmus brevipennis from Amami-Oshima which was collected by R. P. Ferrié.

2. 1897. In his paper on the Coleopterous fauna of Ishigaki Is., L. Fairmaire reported Amarygmus callichromus sp. nov., Eucyrtus multicolor Fairmaire and Alphitobius nitidulus Motschulsky which were presented to him by R. Oberthür.

3. 1897. L. Fairmaire described Strongylium oshimanum which was collected by R. P. Ferrié on Amami-Oshima.

4. 1898. L. Fairmaire described Plesiophthalmus fuscoaenescens from Ishigaki Is. which was collected by R. Oberthür.

5. 1927. In his list of Coleoptera of the Okinawa Prefecture, $\mathrm{H}$. Yashiro reported Tribolium ferrugineum Fabricius.

6. 1931. Y. Miwa recorded Plesiophthalmus fuscoaenescens Fairmaire and Amarygmus callichromus Fairmaire from Ishigaki Is.

7. 1933. In his paper on the Coleopterous fauna of Iriomote Is., Y. Miwa recorded Dicraeosis carinatus Gebien, Eucyrtus multicolor Fairmaire, Campsiomorphus imperialis Fairmaire, Plesiophthalmus fuscoaenescens Fairmaire and Uloma excisa Gebien.

8. 1935. In his paper on the Coleopterous fauna of Amami-Oshima, Y. Miwa reported Setenis oshimanus sp. nov., Mesomorphus villiger Blanchard, Plesiophthalmus brevipennis Lewis, Strongylium oshimanum Fairmaire and Pseudonautes purpurivittatus Murseul.

Before the World War II the descriptions of the Tenebrionidae of the Ryukyu Islands were exclusively found in the above mentioned eight papers and recorded tenebrionid beetles were only 13 species in number belonging to 12 genera. But since 1952, studies on the Tenebrionidae of this islands have started actively and until now, the following 16 papers have so far reported.

9. 1952. In his monograph of the genus Gonocephalum of India, Malay and eastern Asia, Z. Kaszab reported $G$. coenosum Kaszab (H. Sauter coll.) from Ishigaki Is. and G. coriaceum Motschulsky (T. Lenz coll.) from Amami-Oshima.

10. 1956. In his paper on the Coleopterous fauna of Japan, T. 
Nakane described Uloma ichoi from Amami-Oshima and reported Uloma excisa Gebien from Nakanoshima of the Tokara Is.

11. 1959. In his paper on the Coleopterous fauna of the Ryukyu Islands, M. Chûjô recorded Dicraeosis carinatus shirozui Nakane and Pseudonautes purpurivittatus Marseul.

12. 1961 (March). In his revisional work on the genus Derispia, Z. Kaszab described Derispia japonica (J. E. Lewis coll.) from Okinawa Is.

13. 1961 (August). In his revisional work on the tribe Leiochrini, M. Miyatake described Derispia amamiana and D. shibatai Chûjô et Miyatake from Amami-Oshima.

14. 1962. N. Ohbayashi recorded Strongylium oshimanum Fairmaire from Amami-Oshima which was collected by himself and showed the photo-figure of its dorsal view.

15. 1963 (May). In his paper on the Japanese Coleopterous fauna, T. Nakane described Gonocephalum coriaceum takara and Caedius maderi minor from Takarajima of the Tokara Is.

16. 1963 (June, 20). In his revisional work on the Japanese Gonocephalum, M. T. Chûjô described G. okinawanum from Okinawa Is. and Takarajima and reported $G$. coenosum Kaszab from Iriomote Is. and $G$. coriaceum from Amami-Oshima.

17. 1963 (June, 30). In the iconography, T. Nakane illustrated 149 tenebrionid species. Among 30 species are from the Ryukyu Islands.

18. 1963 (June, 30), In this Coleopterous faunal work, S. Nomura reported Strongylium spp. (2 sp. nov., 4 subsp. nov. and 1 known subsp.) from the Ryukyu Islands.

19. 1963 (June). T. Nakane published a second paper of the abovementioned series (19). In this paper, he described 7 spp. nov. and 1 subsp. nov. from the Ryukyu Islands.

20. 1963 (July). In his paper on the Coleopterous fauna of Iriomote Island, M. T. Chûjô recorded 8 tenebrionid species.

21. 1964 (April). Z. Kaszab reported the tenebrionid fauna of Tsushima Is., the Tokara Is. and Amami-Oshima. His work was separated into two parts owing to the editorial reason. This paper was the first half. The outline of the tenebrionid fauna of these three islands, synonymies of several species, list of species on each island, original descriptions of 4 new species and the change of status of 1 known species were treated in this part.

22. 1964 (August). Z. Kaszab reported the second part. In this part, original descriptions of 4 new species, 1 new subspecies and 1 new combination of the known species were given.

23. 1964 (August). In his revisional work on the genus Plesiophthalmus, H. Yamazaki reported P.brevipennis Lewis from Amami-Oshima and 
P. fuscoaenescens Fairmaire from Ishigaki Is., Iriomote Is. and Formosa. 24. 1964 (December). In his paper on the Coleopterous fauna of the Ryukyu Islands and its adjacent regions, S. Nomura described Strongylium uedai and Plesiophthalmus spectabilis okinawanum from Okinawa Is. and recorded Strongylium marseuli yuwanum Nomura from Okinawa Is., Ishigaki Is. and Iriomote Is.

\section{TAXONOMIC ENUMERATION OF THE SPECIES FROM THE RYUKYU ISLANDS

\author{
Subfamily Pedininae Solsky, 1834
}

\section{Diphyrrhinchus iriomotensis sp. nov. (Pl. I: 3a-3d; Pl. II : 1)}

Oblong oval, subparallel, feebly convexed, shiny black, with dark brown legs. Head comparatively flat, coarsely and strongly punctate; frontal suture very shallow but visible; frontal widely and deeply sinuate; eyes oblique, weakly and roundly projected. Antennae 11-segmented, not reaching to base of pronotum; 1-2 longer than 3, 7-10 transverse, apical one rounded, 7-11 forming a very loose club. Maxillary palpus moderate in length, 2 longer than 3 , apical one visibly securiformed. Pronotum very minutely and densely punctate, weakly convexed; front margin shallowly but widely sinuate, lateral margins narrowly marginate, base feebly trisinuate, with a very sharrow and oblique fovea on each side. Scutellum widely taiangular, very minutely and sparsely punctate. Elytra regularly convexed, with nine punctate-striae, 1 mostly reduced, but the other striae distinct and becoming deeper towards apex; interstices very minutely and sparsely punctate, flat at the basal $2 / 3$, slightly convexed towards apex; lateral margin widest near apex. Beneath evenly and slightly pubescent. Gular concave, with surface strongly punctate. Prosterna punctate, punctures on middle $1 / 3$ more scarce than outer sides; prosternal process elongate elliptic, sharpened at apex, scarcely punctured on the surface; mesosternum depressed between middle coxae for receiving prosternal process; metasternum strongly convexed, scarcely and strongly punctured, with the median and posterior marginal sutures visible; abdominal sternites with punctures, longitudinally and finely rugose, 1-3 of same length, penultimate shortest, last two segments movable. Front coxal cavity elliptic, obscure; front femur comparatively thick, with fine pubescence; front tibia strongly widened towards apex, roughly structured on surface, shortly setose on outside, with two spurs at apical corner; front tarsus with golden fine hairs on undersurface, 1 triangle, 2-4 widely bifurcate, 4 shortest, 5 a little shorter than 1 to 4 put together; claws bifurcated, simple. Middle coxal cavity elliptic, obscure, closed outwardly with mesepimera; middle femur with sparse punctures, pubescent; middle tibia widened towards apex, roughly structured and setaceous on surface, with two spurs at apical corner, one long, another short; middle tarsus with golden fine hairs, 1 weakly widened towards apex, 2-4 bifurcated, 4 shortest, apical one nearly equal to $2-4$ put together. Hind coxal cavity transverse, closed with metepisterna; hind tibia dilated towards apex, with rough and setaceous surface, inside of apex with two spurs, one long, another short; hind tarsus dilated towards apex, 1 longest and nearly equal to 3 and 4 put together. 
Metendosternite comparatively complex, with lateral parts of ventral process of furca. Wing venation well developed, with radial sector, $r-m$ cross vein complete, 3rd media rather long, cubitus ( $1 \& 2$ ) and post cubitus well developed, 1st anal vein short but visible.

Length: $4.5-6.0 \mathrm{~mm}$. Width: 2.0-3.0 $\mathrm{mm}$.

Distribution: Ryukyu Is. (Iriomote Is.).

Type materials: Holotype $\hat{o}(\mathrm{CFSRKU})^{3}$ : Ohara, 8-18. viii. 1962, M. T. Chûjô leg.; Paratypes: 1ㅇ․ 2 우우(CFSRKU), Haimida, 9. viii. 1962, M. T. Chûjô leg.; 20 ô, 5 우우 (CFSRKU), Haimizaki, 11. viii. 1962, M. T. Chû jò leg.; 14 f̂f, 1 우 (CFSRKU), Ohara, 1-18. viii. 1962, M. T. Chûjô leg.; 5ㅅํㅇ, 10 우우 (J-US) ${ }^{4}$, Ohara, 3. x. 1963, S. Miyamoto leg.; 1 ㅇ (J-US), Shirahama, 3. x. 1963, S. Uéno leg.; $1 \hat{\delta}$, 2 우이 (J-US), Shirahama, 3. x. 1963, M. Morimoto leg.; 16 占占, 9 우으 (J-US), Shirahama-Sonai, 6.

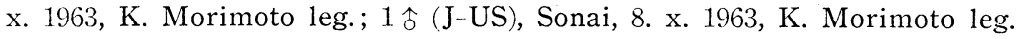

This species is related to D. shibatai Kaszab [1964, Ent. Rev. Japan, 16 (2) : 43-44], but is easily distinguished from it in having the following characters: Body much larger and stouter than D. shibatai Kaszab; lateral margin of pronotum curved moderately, while in D. shibatai Kaszab it is curved more strongly near front corner; elytral suture shallower on near base and deeper near apex; front tibiae more strongly widened towards apex; gular more deeply concaved; punctures of prosternal process shallower; radial cell on the hind wing is present in D. shibatai while it is lacking in the new species.

\section{Diphyrrhinchus shibatai Kaszab}

Diphyrrhinchus shibatai Kaszab, 1964, Ent. Rev. Japan, 16 (2): 43 t4 (AmamiOshima: Asani).

Spec. exam.: 9 spp. (KU)5, Akagina-Ueno, Amami-Oshima, 18. vii. 1954, S. Miyamoto \& Y. Hirashima leg.; 2 spp. (holo- and paratypes) (S) ${ }^{6}$, Asani, AmamiOshima, 19. v. 1960, T. Shibata leg.; 2 spp. (CFSRKU), Haimida, Iriomote Is., 9. viii. 1962, M. T. Chûjô leg.; 4 spp. (CFSRKU), Ohara, Iriomote Is., 8-18. viii. 1962, M. T. Chûjô leg.; 91 spp. (CFSRKU), Haimizaki, Iriomote Is., 11. viii. 1962, M. T. Chûjồ leg.

Distr.: Ryukyu Is. (Amami-Oshima \& Iriomote Is.*).

Note: According to the original description the colour of this species is as follows: "Körper dunkel pechbraun, mit sehr schwachem Bronzeschimmer." But many shiny black coloured specimens are found in our collection.

${ }^{3}$ Committee of Foreign Scientific Research of Kyushu University.

4 Japan-U. S. Co-operative Science Program.

5 Entomological Laboratory of Kyushu University.

${ }^{6}$ Mr. Taichi Shibata. 


\section{Subfamily Opatrinae Laporte, 1840}

\section{Mesomorphus villiger (Blanchard)}

Mesomorphus villigerum Blanchard, 1853, Voy. Pôle Sud, Zool. 4: 154, Pl. x. Fig 15 (New Guinea: Triton Bay).

Mesomorphus villiger (Blanchard), Miedel, 1880, Deutsche Ent. Zeitschr., 24 (1): 40 (Morphology).-Miwa, 1935, Trans. Kansai Ent. Soc., (6) : 22 (Oshima: Naze).-Nakane, 1963, Iconogr. Ins. Japonicorum, Colore nat. edit. 2 (Col.): 221, Pl. cxi, Fig. 4 (Japan: Honshn \& Kyushu; Amami-Oshima).

Opatrum villigerum (Blanchard), Lewis, 1894, Ann. Mag. Nat. Hist., (6), 13 (77): 382 (Japan: Kobé).

= Mesomorphus dermestoides Reitter, 1904, Best.-Tab. europäischen Col., 53 (3): 74 (Central China, Tientsin \& Hongkong).

= Mesomorphus dispersus Champion, 1894, Trans. Ent. Soc. London: 361 (N. W. Australia: Port Darwin).

= Mesomorphus mustelinus Fairmaire, 1882, Notes Leyden Mus., 4: 221 (Tropical Africa).

= Mesomorphus puberulus Fairmaire, 1867, Bull. Linn. Soc. Normandy, (2), 1: 187, nota (Madagascar).

Spec. exam.: 1 sp. (KU), Shinmura, Amami-Oshima, 23. vii. 1954, S. Miyamoto \& Y. Hirashima leg.; 1 sp. (C) $)^{7}$, Shuri, Okinawa, 9. iv. 1958, H. Nakachi leg.

Distr.: New Guinea, Samoa, Indonesia, Malaysia, Viet-Nam, Cambodia, Thailand, China, Formosa, Korea, Japan, Ryukyu Is. (Amami-Oshima \& Okinawa Is.) and Micronesia.

\section{Gonocephalum coenosum Kaszab}

Gonocephalum coenosum Kaszab, 1952, Ent. Arb. Mus. G. Frey, 3 (2): 454, 643-646 \& 682-683, Figs. 413-415 (China: many localities, incl. Chusan \& Hainan Is.; Japan: many localities, incl. Tsushima Is.; Formosa: many localities; Ryukyu Is.: Ishigaki Is.; Korea: Quellpart).-M. T. Chûjô, 1963, Kontyû, 31 (2); 153 (Ryukyu Is. : Ishigaki Is. \& Iriomote Is.; Japan Honshu, Shikoku \& Tsushima Is.).-M. T. Chûjô, 1963, Rep. Comm. Foreign Sci. Res., Kyushu Univ., 1: 93 (Ryukyu Is.: Iriomote Is.).

= Opatrum (Gonocephalum) japanum (nec Motschulsky, 1860) Marseul, 1876, Ann Soc. Ent. France, (5), 6: 96 (Kiu-Siu \& Niphon).

=Gonocephalum depressum (nec Fabricius, 1798) Miwa, 1931, Syst. Cat. Formosan Col.: 152 (Formosa: Hôkotô, Arisan \& Horisha).

-Gonocephalum recticolle (nec Motschulsky, 1866) Kaszab, 1941, Stettiner Ent Zeit., 102: 51 (Formosa: Takao, Pilam, Lake Candidius, Tainan \& Kagi).

Spec exam.: 2 spp. (KU), Shika-Kabira, Ishigaki Is., 24. vii. 1954, T. Esaki leg.; 24 spp. (CFSRKU), Ohara, Iriomote Is., 8-18. viii. 1962, M. T. Chûjồ leg.; $1 \mathrm{sp.}$ (CFSRKU), Komi-Ohara, Iriomote Is., 14. vii. 1963, Y. Miyatake leg.: 4 spp. (J-US)。 Ohara, Iriomote Is., 1. x. 1963, Y. Hirashima leg.; 2 spp. (J-US), Ohara Iriomote Is.; 2. x. 1963, S. Miyamoto leg.; 44 spp. (J-US), Ohara, Iriomote Is., 2. x. 1963, K Morimoto leg.; 7 spp. (J-US), Isobe $0-1 \mathrm{~m}$., Ishigaki Is., 30. x. 1963, G. A. Samuel son leg.; 7 spp. (J-US), Ohara, Iriomote Is., 31. x. 1963, G. A. Samuelson leg.

i Michitaka Chûjô.

* Asterisk shows the species which has hitherto been unrecorded from the district. 
Distr.: China, Formosa, Japan and Ryukyu Is. (Ishigaki Is. \& Iriomote Is.).

\section{Gonocephalum coriaceum Motschulsky}

Gonocephalum coriaceum Motschulsky, 1857, Etud. Ent., 6: 34 (Japan).-Kaszab, 1952, Ent. Arb. Mus. G. Frey, 3 (2): 458, 667-668 \& 685, Figs. 499-503 (Manchuria ; China: several localities, incl. Chusan Is. \& Namoa Is.; Japan many localities, incl. Tsushima Is. \& Sado Is.; Liu-Kiu: Oshima).

Opatrum (Gonocephalum) coriaceum (Motschulsky), Marseul, 1876, Ann. Soc. Ent. France, (5), 6: 96 (Japan: Kiu-Siu).

Hopatrum coriaccum (Motschulsky), Lewis, 1879, Cat. Col. Japanese Archipel.: 18 (Japan).

Opatrum (Gonocephalum?) coriaceum (Motschulsky), Heyden, 1879, Deutsche Ent. Zeitschr., 23 (2): 353 (Japan: Osaka \& Kiushiu).

Opatrum coriaceum (Motschulsky), Harold, 1876, Abh. Nat. Ver. Bremen, 5; 130 (Japan).

Gonocephalum (Gonocephalum) coriaceum (Motschulsky), Reitter, 1904, Best.-Tab. europäischen Col., 53 (3): 142-143 (Japan; Mongolia; Sze-tschuan).

Spec. exam.: None.

Distr.: Japan (Hokkaido, Honshu, Sado Is., Shikoku, Kyushu \& Tsushima Is.), Ryukyu Is. (Amami-Oshima), Korea, China and Manchuria.

\section{Gonocephalum moluccanum (Blanchard)}

Opatrum moluccanum Blanchard, 1853, Voy. Pôle Sud. Zool., 4: 153 (Molucca Is.). Gonocephalum moluccanum (Blanchard), Gebien, 1910, Junk-Schenkling's Col. Cat., 22: 324 (Moluccen).--Kaszab, 1964, Ent. Rev. Japan, 16 (2): 40 (Tokara Is.: Takarajima).

= Hopatrum arenarium Fairmaire, 1893, Ann. Soc. Ent. France, 62: 20 (India \& Ceylon).

= Gonocephalum coriaccum (nec Motschulsky, 1857), Miwa, 1931, Syst. Cat. For . mosan Col.: 152 (Formosa: Kankau, Tainan, Anping, Kôsempo \& Garambi).

=Gonocephalum aurifalcifer Schaufuss, in litt.

=Gonocephalum planatum Walker, 1858, Ann. Mag. Nat. Hist., (3) 2: 284 (Ceylon).

Spec. exam.: 2 spp. (S), Takarajima, Tokara Is., 2. vii. 1960, Y. Hama leg.; 1 sp. (S), Takarajima, Tokara Is., 2. vii. 1960, M. Sato leg.; 1 sp. (CFSRKU), Ohara, Iriomote Is., 8-18. viii. 1962, M. T. Chûjô leg.; 5 spp. (J-US), Ohara, Iriomote Is., 1. x. 1963, Y. IIrashima leg.; 4 spp. (J-US), Ohara, Iriomote Is., 2. x. 1963, S. Miyamoto leg.; 7 spp. (J-US), Ohara, Iriomote Is., 2. x. 1963, K. Morimoto leg. Distr.: India, Ceylon, Andamans, Indo-China, Major \& Lesser Sunda Is., Celebes, Moluccas, New Guinea, Philippines, China, Hainan Is., Formosa, Ryukyu Is. (Tokara Is.) and Japan.

\section{Gonocephalum okinawanum M. T. Chûjô}

Gonoccphalum okinawanum M. T. Chûjô, 1963, Kontyû, 31 (2): 149-151 (Okinawa Is. : Hentona ; Tokara Is.: Takarajima).--Nakane, 1963, Iconogr. Ins. Japonicorum, Colore nat. edit. 2 (Col.): 222, Pl. cxi, Fig. 15 (Tokara Is.: Takarajima; AmamiOshima; Ryukyu Is.).-Kaszab, 1964, Ent. Rev. Japan, 16 (2): 40-43 (Tokara Is. : Takarajima \& Nakanoshima; Amami-Oshima). 
Spec. exam.: 2 spp. (KU), Akagina, Amami-Oshima, 17. vii. 1954, S. Miyamoto \& Y. Hirashima leg.; 1 sp. (holotype) (KU), Hentona, Okinawa Is., 28. iv. 1958, K. Iha leg.; 9 spp. (paratype) (C), same data with holotype; 1 sp. (S), Asani, AmamiOshima, 19. v. 1960, T. Shibata leg.; 4 spp. (C), Takarajima, Tokara Is., 2. vii. 1960 , M. Sato leg.; 1 sp. (CFSRKU), Haimida, Iriomote Is., 9. viii. 1962, M. T. Chûjô leg. ; 2 spp. (J-US), Ohara, Iriomote Is., 2. x. 1963, K. Morimoto leg.

Distr.: Ryukyu Is. (Tokara Is., Amami-Oshima, Okinawa Is. \& Iriomote Is.*).

\section{Gonocephalum pubens Marseul}

Opatrum pubens Marseul, 1876, Ann. Soc. Ent. France, 6 (5): 97 (Japan).

=Gonocephalum pubens (Marseul), Gebien, 1910, Junk-Schenkling's Col. Cat., 22 : 324 (Japan).

Spec. exam.: 1 sp. (J-US) Ohara, Iriomote Is., 1. x. 1963, Y. Hirashima leg.

Distr: Manchuria, China, Japan (Honshu \& Kyushu), Ryukyu Is. (Iriomote Is. ${ }^{*}$, Korea, Formosa and India.

\section{Gonocephalum takara Nakane}

Gonocephlaum coriaceum takara Nakane, 1963, Fragm. Col., (6): 26 (Tokara Is.: Takarajima); 1963, Iconogr. Ins. Japonicorum, Colore nat. edit. 2 (Col.): 222, P1. cxi, Fig. 14b (Tokara Is.: Takarajima).

Gonocephalum lakara Nakane, Kaszab, 1964, Ent. Rev. Japan, 16 (2): 40 \& 44-45 (Tokara Is.: Takarajima).

Spec. exam.: 2 spp. (C), Takarajima, Tokara Is., 2. vii. 1960, M. Sato leg.; 1 sp., (CFSRKU) Haimizaki, Iriomote Is., 9. viii. 1962, M. T. Chûjô leg.; 2 spp. (J-US), Ohara, Iriomote Is., 2. x. 1963, K. Morimoto leg.

Distr.: Kyukyu Is. (Tokara Is. \& Iriomote Is.*).

Notes: This species was at first described by T. Nakane (1963) as a subspecies of $G$. coriaceum Motschulsky (1857). But, later Z. Kaszab (1946) treated this species as an independent species in his paper "The Entomological Review of Japan, 16 (2): 40 \& 44-45”. I agree with $Z$. Kaszab's opinion

\section{Caedius maderi Kaszab}

Caedius maderi Kaszab, 1942, Mitteil. Münchner Ent. Ges., e. V., 32 (1): 35-36 (Japan: Oita in Kyushu).-Kaszab, 1964, Ent. Rev. Japan, 16 (2): 40 ?(Tokara Is.: Takarajima).

= Caedius maderi minor Nakane, 1963, Fragm. Col., (6): 26 (Tokara Is.: Takara jima); 1963, Iconogr. Ins. Japonicorum, Colore nat. edit. 2 (Col.): 222, Pl. cxi. Fig. 17b (Tokara Is.: Takarajima).-Kazsab, 1964, Ent. Rev. Japan, 16 (2): 40 (new synonym).

Spec. exam.: 4 spp. (C), Takarajima, Tokara Is., 3. vii. 1960, M. Sato leg.

Distr.: Japan (Honshu, Izu Is., Shikoku \& Kyushu), Ryukyu Is. (Tokara Is.) and Cambodia.

Notes: T. Nakane (1963) recorded the specimens collected in the Tokara Islands as a subspecies of C. maderi, but Z. Kaszab (1964) expressed his opinion that Nakane's subspecies may be a synonym of $C$. 
maderi. I examined many specimens of this species collected in Japan (Honshu, Shikoku \& Kyushu), Ryukyu Is. (Tokara Is.), Cambodia, etc. and came to the conclusion that the subspecific characters enumerated by $\mathrm{T}$. Nakane for the Tokara specimens are nothing but individual variations.

\section{Caedius minimus sp. nov. (P1. II : 2)}

Body oval, convexed; whole surface densely granulated, with golden short hairs; general colour piceous to dark brown; antennae and legs reddish brown. Head roughly granulated, preocular area narrow and parallel, frontal suture invisible, frontal margin deeply sinuate; eyes obscurely and narrowly depressed, widely separated from each other. Antennae thick and short, 1 larger than 2, 3 very narrowed at base, 4-10 transverse, 6-10 forwardly projected, 3-10 gradually sidened, 10 widest and longest, apical one rounded; maxillary palpus with securiformed apical segment. Pronotum transverse, lateral margins very weakly rounded, front corner rounded, frontal margin widely and deeply sinuate, hind margin rounded. Scutellum smooth, very small triangle. Elytra widest at $1 / 3$ from base, lateral margins forming an elliptic curve. Gular suture invisible. Pronotum with long hairs near margins; prosternal process elliptic, surface very rough, feebly depressed; mesosternum depressed between middle coxal cavities for receiving prosternal process; mesepimeron scaresely reaching to middle coxal cavity; metasternum short; 3rd visible abdominal sternite shortest, apical one 2.5 times as long as 3rd, last two movable. Front and middle coxae round, hind coxae transverse; femur very thick, with comparatively long hairs, roughly granulated; front tibia flat extremely dilated towards apex, inside margin feebly curved inwardly, outside margin with a thick and obtuse projection, apical side of projection deeply sinuated, surface generally smooth, with an oblique groove for receiving tarsus, a few granules on undersurface, large and sharp spurs at apex; hind tarsus a little slender, feebly curved outwardly, with scarece setae on outside and two spurs at apex; front tarsus very fine, 1-4 almost of equal length, apical one rather thick, nearly equal to $2-1$ put together; middle tarsus with rather thick hairs at apex of each segment, each segment dilated towards apex, $1-2+3,4$ shortest, $2+3+4=5$; hind tarsus rather long, each segment dilated towards apex, 1 longest, 2 larger than 3 , apical one longer than $2+3$. Hind wing completely reduced.

Length: $3.0-3.5 \mathrm{~mm}$. Width : $1.5-1.8 \mathrm{~mm}$.

Distribution: Ryukyu Is. (Iriomote Is.).

Type malerials: Holotype ô (CFSRKU), Haimida, Iriomote Is., 9. viii. 1962, M. T. Chûjô leg. Paratypes: 11 占占, 12 우우 (CFSRKU), same data as holotype; 2송, 2 우 (CFSRKU), 11. viii. 1962, M. T. Chûjô leg.

This species is related to C. maderi Kaszab, 1942, from Kyushu, Japan, but may easily be distinguished from it by the following characters. This species is much smaller in general size, Pronotal hind margin of $C$. maderi is bisinuate but in this species it is evenly rounded. Sinuated part of front tibia of this species is smooth but in C. maderi it has two obtuse small projections. 


\section{Subfamily Trachyscelinae Mulsant, 1854}

\section{Trachyscelis chinensis Champion}

Trachyscelis chinensis Champion, 1894, Ann. Mag. Nat. Hist., 14 (6): 448 (China).-Kaszab, 1964, Ent. Rev. Japan, 16 (2): 41 (Tokara Is.: Takarajima).

Spec. exam.: None.

Distr.: China and Ryukyu Is. (Tokara Is.)

\section{Subfamily Phaleriinae Mulsant, 1854}

\section{Micropedinus pallidipennis Lewis}

Micropedinus pallidipenne Lewis, 1894, Ann Mag. Nat. Hist., (6), 13 (77): 380 (Japan: Kobé).-M. T. Chûjô, 1963, Rep. Comm. Foreign Sci. Res., Kyushu Univ., 1: 93 (Ryukyu Is.: Ohara \& Nagahama in Iriomote Is.).-Kaszab., 1964, Ent. Rev. Japan, $16(2): 42$ (Amami-Oshima: Asani).

Spec. exam.: 14 spp. (KU), Akagina, Amami-Oshima, 17. vii. 1954, S. Miyamoto \& Y. Hirashima leg.; 14 spp. (KU), Akagina-Ueno, Amami-Oshima, 18. vii. 1954, S. Miyamoto \& Y. Hirashima leg.; 3 spp. (S), Asani, Amami-Oshima, 19. v. 1960, T. Shibata leg.; 1 sp. (S), Ikari, Amami-Oshima, 21. v. 1960, T. Shibata leg.; 5 spp. (CFSRKU), Haimizaki, Iriomote Is., 11. viii. 1962, M. T. Chûjô leg.; 1 sp (CFSRKU), Qhara, Iriomote Is., 8-18. viii. 1962, M. T. Chûjô leg. ; 2 spp. (CFSRKU), Nagahama, Iriomote Is., 20-21. viii. 1962, M. T. Chûjô leg; 4 spp. (J-US), Shirahama, Iriomote Is., 3. x. 1963, K. Morimoto leg.; 2 spp. (J-US), Shirahama, Iriomote Is., 3. x. 1963, S. Uéno leg.

Distr.: Japan (Hokkaido, Honshu, Shikoku \& Kyushu) and Ryukyu Is. (AmamiOshima \& Iriomote Is.).

\section{Subfamily Bolitophaginae Mulsant, 1854}

\section{Dicraeosis carinatus carinatus Gebien}

Dicracosis carinatus carinatus Gebien, 1913, Arch. f. Naturg., 79, A (9): 12 (Formosa: Kankau, Hoozan \& Sokutsu).--Miwa, 1933, Trans. Nat. Hist. Soc. Formosa, 23 (124): 9 (Loochoos: Iriomote Is.).

Spec. exam.: 2 spp. (KU), Bannadake, Ishigaki Is., 24. vi. 1934, T. Esaki leg. : 1 sp. (KU), Bannadake, Ishigaki Is., 1. vii. 1934, T. Esaki leg.; 2 spp. (BM) $)^{8}$, Iriomote Is., 20. viii. 1934, J. L. Gressitt leg.; 1 sp. (BM), Iriomote Is., 21. viii. 1934, J. L. Gressitt leg.; 1 sp. (BM), Ishigaki Is., 20-30. xi. 1952, G. E. Bohart leg.; 1 sp. (BM), Ishigaki Is., 10 15. xii. 1952, G. E. Bohart leg.; 3 spp. (BM), Ishigaki Is., 10-20. xii. 1952, G. E. Bohart leg.; 1 sp. (J-US), Yuwan, Amami-Oshima, 29. vii. 1963, Y. Hirashima leg.; 1 sp. (J-US), Yuwan-dake 300-600 m., Amami-Oshima, 31. vii. 1963, J. L. Gressitt leg.; 1 sp. (J-US), Bannadake, Ishigaki Is., 1. x. 1963, K. Morimoto leg.; 1 sp. (J-US), Ushikumori, Iriomote Is., 11. x. 1963, S. Kuniyoshi leg.; 1 sp. (J-US), Omotodake, Ishigaki Is., 14. x. 1963, S. Uéno leg.; 1 sp. (J-US), Minamimeijiyama, Okinawa Is., 20. x. 1963, S. Uéno leg.; 1 sp. (J-US), Izumi,

${ }^{8}$ B. P. Bishop Museum. 
Okinawa Is., x. 1963, no collecter's name; 1 sp. (J-US), Ushikumori $350 \mathrm{~m}$., Iri. omote Is., 2. xi. 1963, G. A. Samuelson leg.; 1 sp. (J-US), Kara-yama, Ishigaki Is., 14 18. iv. 1964, C. M. Yoshimoto \& J. Harrell leg.; 1 sp. (J-US), Gogayama, Okinawa Is., 17. v. 1964, T. Kakinohana leg.; 1 sp. (J-US), Omoto-dake 100-250 m., Ishigaki Is., 22. v. 1964, J. L. Gressitt leg.

Distr.: Formosa and Ryukyu Is. (Iriomote Is., Ishigaki Is.* \& Okinawa Is.*).

\section{Byrsax japonicus Lewis}

Byrsa.x japonicus Lewis, 1894, Ann. Mag. Nat. Hist., (6), 13 (77): 388 (Japan : Nara). - Kaszab, 1964, Ent. Rev. Japan, 16 (2): 42 (Amami-Oshima: Ikari).

Spec. cxam.: 1 sp. (S), Ikari, Amami-Oshima, 17. v. 1960, T. Shibata leg.

Distr.: Japan (Honshu \& Shikoku) and Ryukyu Is. (Amami-Oshima).

\section{Subfamily Diaperinae Redtenbacher, 1845}

\section{Diaperis lewisi intersecta Gebien}

Diapcris lewisi Bates var. intersecta Gebien, 1913, Arch. f. Naturg., 79A (9): 15 (Formosa: Fuhosho; China: Hongkong).

Diapcris lewisi intersecta Gebien, 1939, Kat. Tenebr., 2: (525) (Formosa \& Hongkong). Nakane, 1963, Iconogr. Ins. Japonicorum, Colore nat. edit. 2 (Col.): 223, Pl. cxii, Fig. 11b (Nansei Is. \& Formosa).

Spcc. cxam.: 1 sp. (KU), Ishigaki Is., 3. ix. 1936, T. Iwasaki leg.; 4 spp. (KU), Naze, Amami-Oshima, 19. vii. 1954, S. Miyamoto \& Y. Hirashima leg.; 7 spp. (CFSRKU), Upper Urauchi Riv., Iriomote Is., 9. vii. 1963, Y. Miyatake leg.; 17 spp. (CFSRKU), Komi, Iriomote Is., 19. vii. 1963, Y. Miyatake leg.; 16 spp. (J-US), Shirahama, Iriomote Is., 4. x. 1963, K. Morimoto leg.

Distr: Formosa, Ryukyu Is. (Amami-Oshima, Ishigaki Is. \& Iriomote Is.), Hongkong, Viet-Nam, Laos and Burma.

\section{Diaperis sanguinipennis sinensis Gebien}

Diaperis sanguinipennis sinensis Gebien, 1925, Monogr. Tenebr.: 155 \& 156 (China, Hongkong; Canton).-Kaszab, 1964, Ent. Rev. Japan, 16 (2): 41 (Tokara Is.: Nakanoshima \& Takarajima).

Spec. exam.: 1 sp. (S), Takarajima, Tokara Is., 2. vii. 1960, Y. Hama leg. Distr.: China and Ryukyu Is. (Tokara Is.).

\section{Scaphidema pictipenne Lewis}

Scaplidema pictipenne Lewis, 1894, Ann. Mag. Nat. Hist., (6), 13 (77): 397 (Japan: Nara).-Kaszab, 1964, Ent. Rev. Japan, 16 (2): 42 (Amami-Oshima: Ikari). Spcc. exam.: 1 sp. (S), Ikari, Amami-Oshima, 22. vi. 1960, T. Shibata leg. Distr.: Japan (Honshu) and Ryukyu Is. (Amami-Oshima).

\section{Platydema fumosum Lewis}

Platydema fumosum Lewis, 1894, Ann. Mag. Nat. Hist., (6), 13 (77): 395-396 (Japan. 
Kioto \& Nara).-Kaszab, 1964, Ent. Rev. Japan, 16 (2); 42 (Amami-Oshima : Hatsuno).

Spec. exam.: 1 sp. (S), Hatsuno, Amami-Oshima, 25. v. 1960, T. Shibata leg.; 5 spp. (J-US), Omoto-dake, Ishigaki Is., 29. x. 1963, Y. Hirashima leg.

Distr.: Japan (Honshu) and Ryukyu Is. (Amami-Oshima).

\section{Platydema marseuli Lewis}

Platydema marseuli Lewis, 1894, Ann. Mag. Nat. Hist., (6), 13 (77): 393-394 (Japan: Nagasaki, Kumamoto, Miyanoshita, Kadzusa \& Yokohama).-Nakane, 1963, Iconogr. Ins. Japonicorum, Colore nat. edit. 2 (Col.): 224, Pl. cxii, Fig. 20 (Japan: Honshu, Shikoku \& Kyushu; Tokara Is.).--M. T. Chûjô, 1963, Rep. Comm. Foreign Sci. Res., Kyushu Univ., 1: 93 (Ryukyu Is.: Ohara and Gozadake in Iriomote Is.).-Kaszab, 1964, Ent. Rev. Japan, 16 (2): 41 \& 42 (Tokara Is.: Nakanoshima, Amami-Oshima: Ikari).

- Platydema nigroaeneum (nec Motschulsky, 1960) Marseul, 1876, Ann. Soc. Fnt. France, 6 (5): 105 [Japan: Kiusiu (Nagasaki)].

Spec. exam.: 1 sp. (S), Ikari, Amami-Oshima, 14. vi. 1960, T. Shibata leg.; 1 sp. (CFSRKU), Goza, Iriomote Is., 14. viii. 1962, M. T. Chûjô leg.; 4 spp. (CFSRKU), Ohara, Iriomote Is., 8-18. viii. 1962, M. T. Chûjô leg.; 3 spp. (J-US) Tarogawa, Ishigaki Is., 17. iii. 1964, C. M. Yoshimoto \& J. Harrell leg.

Distr.: Japan (Honshu, Shikoku \& Kyushu), Ryukyu Is. (Amami-Oshima, Tokara Is., Ishigaki Is. \& Iriomote Is.) and Sunda Is.

\section{Platydema pallidicolle Lewis}

Platydema pallidicolle Lewis, 1894, Ann. Mag. Nat. Hist., (6), 13 (77): (Japan: at Bunkenji in Yokohama).-Kaszab, 1964, Ent. Rev. Japan, 16 (2): 41 (Tokara Is.: Takarajima \& Nakanoshima).

Spec. exam.: 11 spp. (KU), Yuwan-Shinmura, Amami-Oshima, 22. vii. 1954, S. Miyamoto \& Y. Hirashima leg.; 1 sp. (C), Takarajima, Tokara Is., 3. vii 1960, M. Sato leg.; 1 sp. (CFSRKU), Otomi, Iriomote Is., 12-13. viii. 1962, M. T. Chûjô leg. Distr.: Japan (Honshu), Ryukyu Is. (Amami-Oshima*, Tokara Is. \& Iriomote Is.*) and Formosa.

\section{Platydema subfascia (Walker)}

Alphitophagus subfascia Walker, 1858, Ann. Mag. Nat. Hist., (3), 2 (10): 284 (Ceylon Is.).

Platydema subfascia (Walker), Gebien, 1911, Junk-Schenkling's Col. Cat., 28: 377 (India, Sunda Is., S. China, etc.).-Nakane, 1963, Iconogr. Ins. Japonicorum, Colore nat. edit. 2 (Col.): 225, Pl. cxiii, Fig. 6 (Japan: Honshu, Shikoku \& Kyushu; Nansei Is.).-M. T. Chûjô, 1963, Rep. Comm. Foreign Sci. Res. Kyushu Univ., 1: 93 (Ryukyu Is.: Ohara in Iriomote Is.).-Kaszab, 1964, Ent. Rev. Japan, 16 (2): 41 (Tokara Is.: Takarajima \& Nakanoshima).

= Platydema celebum Chevrolat, 1877, Pet Nouv. Ent., 2: 177 (Sunda Is.).

=Platydema diversidens Fairmaire, 1893, Ann. Soc. Ent. France, 6 (5): 109-111 (Niphon: Hiogo).

= Basides picicollis Motschulsky, 1873, Bull. Hist. Nat. Moscou, 46 (1): 474 (India).

=Platydema picicolle (Motschulsky), Gebien, 1940, Kat. Tenebr., 2: (534) (Synonymized). 
Spec. exam.: 1 sp. (BM), Ishigaki Is., xi-xii. 1952, G. E. Bohart leg.; 1 sp. (KU), Yuwan-Shinmura, Amami-Oshima, 22. vii. 1954, S. Miyamoto \& Y. Hirashima leg. 1 sp. (KU), Nishinakama, Amami-Oshima, 25. vii. 1954, S. Miyamoto \& Y. Hirashima leg.; 2 spp. (S), Ikari, Amami-Oshima, 11. v. 1960, T. Shibata leg.; 2 spp. (S), Ikari, Amami-Oshima, 17. v. 1960, T. Shibata leg.; 2 spp. (S), Ikari, AmamiOshima, 18. v. 1960, T. Shibata leg. ; 1 sp. (S), Ikari, Amami-Oshima, 22. v. 1960, T. Shibata leg.; 10 spp. (C), Nakanoshima, Tokara Is., 7. vii. 1960, M. Sato leg.; 1 sp. (KU), Otomi, Iriomote Is., 21. xi. 1960, K. Yasumatsu leg.; 1 sp. (CFSRKU) Ohara, Iriomote Is., 12-13. viii. 1962, M. T. Chûjô leg.; 108 spp. (CFSRKU), Ohara, Iriomote Is., 8-18. viii. 1962, M. T. Chûjó leg.; 9 spp. (CFSRKU), Ohara, Iriomote Is., 27-31. viii. 1962, M. T. Chûjô leg. ; 7 spp. (CFSRKU), Upper Urauchi Riv., Iriomote Is., 9. vii. 1963, Y. Miyatake leg.; 3 spp. (CFSRKU), Komi, Iriomote Is., 18. vii. 1963, Y. Miyatake leg.; 18 spp. (CFSRKU), Komi, Iriomote Is., 19. vii. 1963, Y. Miyatake leg.; 1 sp. (J-US), Yuwan, Amami-Oshima, 29-31. vii. 1963, Y. Hirashima leg.; 8 spp. (J-US), Ohara, Iriomote Is., 2. x. 1963, S. Uéno leg.; 2 spp. (J-US), Ushikumori, Iriomote Is., 4. x. 1963, S. Uéno leg.; 1 sp. (J-US), Shirahama, Iriomote Is., 4. x. 1963, S. Uéno leg.; 19 spp. (J-US), Shirahama, Iriomote Is., 4. x. 1963, K. Morimoto leg.; 1 sp. (J-US), Ushikumori, Iriomote Is., 4. x. 1963, S. Miyamoto leg.; 1 sp. (J-US), Sonai, Iriomote Is., 6. x. 1963, K. Morimoto leg.; 15 spp. (J-US), Ushikumori, Iriomote Is., 7. x. 1963, S. Uéno leg.; 1 sp. (JUS), Shirahama, Iriomote Is., 7. x. 1963, S. Uéno leg.; 1 sp. (J US), Yoshiwara, Ishigaki Is., 15. x. 1963, K. Morimoto leg.; 5 spp. (J-US), Mt. Ooura 25 m., Ishigaki Is., 27. x. 1963, G. A. Samuelson leg.; 6 spp. (J-US), Bannadake, Ishigaki Is., 28. x. 1963, Y. Hirashima leg.; 1 sp. (J-US), Mt. Banna 150 m., Ishigaki Is., 28. x. 1963, G. A. Samuelson leg.; 19 spp. (J-US), Omotodake, Ishigaki Is., 29. X. 1963, Y. Hirashima leg.; 6 spp. (J-US), Mt. Omoto 100-250 m., Ishigaki Is., 29. x. 1963, G. A. Samuelson leg.; 4 spp. (J-US), Omoto-dake, Ishigaki Is., 16. iii. 1964, C. M. Yoshimoto \& J. Harrell leg.

Distr.: Madagascar, India, Ceylon, Sunda Is., S. China, Formosa, Japan (Honshu, Shikoku, Kyushu \& Tsushima Is.), Bonin Is. and Ryukyu Is. (Tokara Is., Ishigaki Is.* \& Iriomote Is.).

\section{Basanus amamianus sp. nov. (Pl. I : 1a-1d; Pl. II : 3)}

Body oblong oval; general colour black; two basal fascia and two apical spots on the elytra red; ventral surface and tarsi brown. Whole surface covered with very fine, golden pubescence. Head densely punctured; frons depressed; gena warped; eyes roundly projecting at each side. Antennae 1/3 of body length, with thick, short golden hairs, 11-segmented, 1 comparatively slender, 2 transverse, $1 / 3$ of $1,3=1+2,4-6$ of equal length, each of them thicker than $3,7-10$ of nearly equal length, each of 4-10 thickened towards apex, apical one oblong oval. Maxillary palpus 4-segmented, basal one short, oblique, 2 thickened towards apex, $3=1 / 2$ of 2 , rounded, apical one oblong oval, $2+3-$ apical one. Pronotum weakly convexed, roughly, irregularly punctured, front and lateral margins marginated, front margin widely sinuate. Scultellum smooth, parabolic. Elytra convexed, visibly marginated, shallowly striate-punctate, interstices irregularly punctured; subhumeral, transverse fascia forwardly with three waves, middle tooth longest, backwardly with four waves; subapical spots small, oval. Ventral surface with even, very fine, golden pubescence. Pronotum without punctation except pro- 
sternal process, prosternal process projected backwardly, roughly punctured. Mesosternum with strongly punctured triangular areas at both sides; mesepimeron and metasternum without punctation; metapleuron strongly punctured. Visible abdominal sternites with even, fine punctation. Front and middle coxal cavity rounded; hind coxal cavity transverse. Femur flat; front femur with a shallow groove for the reception of tibia. Tibia slender, with short hairs, two spurs at apex. Front tarsus comparatively short; $1=2+3,4$ shortest, apical one nearly equal to 1-3 put together; hind tarsus long, slender, 1 longest, 3 shortest, 3 plus apical one nearly equal to 1 . Wing with a reduced and shortened 3rd media, without 1st cubitus and anal vein; 2nd cubitus separated to two; $r$-s cross vein short but visible; without subcubital fleck. Metendosternite simple Y-shaped; stalk short and narrow.

Length: $6.0-7.5 \mathrm{~mm}$. Width: $3.0-3.5 \mathrm{~mm}$.

Distribution: Ryukyu Is. (Amami-Oshima).

Type materials: Holotype $\hat{o}(\mathrm{KU})$, Ikari, Amami-Oshima, 22. v. 1960, T. Shibata leg. Paratypes 2 令 \& 3 우 (S \& C), Ikari, Amami-Oshima, 22. v. 1960, T. Shibata leg.

This pretty species is very closely allied to B. tsushimensis M. T. Chûjô, 1963, from Tsushima Is., Japan and Mt. Kongo, Korea. The present species is generally smaller than B. tsushimensis M. T. Chûjô. In B. tsushimensis M. T. Chûjô, 3rd media and post cubitus of hind wings are clearly present while in the present species they are reduced and invisible. In addition, the male genitalia of the present species is shorter and the curvature is more weak in lateral view.

Z. Kaszab recorded B. presuturalis Pic [1964, Ent. Rev. Japan, 16 (2) : 42] from Amami-Oshima. According to my present reexamination of the example from Amami-Oshima which was identified as B. presuturalis Pic and returned to the collector from $Z$. Kaszab, is identical with the present new species. B. presuturalis Pic is generally larger than both of the present species and B. tsushimensis M. T. Chûjô.

Note: The following is Pic's original description of $B$. presuturalis:

Basanus presuturalis n. sp. Elongatus, nitidus, niger, elytris antice luteo undulato-fasciatis et ante apicem $\boldsymbol{a d}$ suturam luteo notatis, his striato-punctatis, intervallis multi punctatis. Long. 8 mill. Laos (ex Vitalis).--Distinct, à première vue. de javanus Chev. par la position présuturale de la macule postérieure claire des élytres.

\section{Alphitophagus plagiatus Marseul}

Alphitophagus plagiatus Marseul, 1876, Ann. Soc Ent. France, 6 (5): (Japan).

Spec. exam.: 1 sp. (BM), Ishigaki Is., xi-xii. 1952, G. E. Bohart leg.; 10 spp. (J-

US), Tarogawa, Ishigaki Is., 17. iii. 1964, Y. Miyatake leg.

Distr.: Japan \& Ryukyu Is. (Ishigaki Is.*)

\section{Ceropria induta induta (Wiedemann)}

Helops induta Wiedemann, 1819, Zool. Mag., 1 (3): 164 (Java). 
Ceropria induta (Wiedemann), Harold, 1877, Stettiner Ent. Zeit., 38: 351 (Har. Mon. 351).-Nakane, 1963, Iconogr. Ins. Japonicorum, Colore nat. edit. 2 (Col.): 226, P1. cxiii, Fig. 14 (Japan: Honshu, Shikoku, \& Kyushu; Nansei Is.).-Kaszab, 1964, Ent. Rev. Japan, 16 (2): 41 (Tokara Is.: Nakanoshima).

Ceropria induta induta (Wiedemann), Gebien, 1940, Kat. Tenebr., 2: (548)-(549) (India, Japan, China, Philippines \& Sunda Is.).-M. T. Chûjô, 1963, Rep. Comm. Foreign Sci. Res., Kyushu Univ., 1: 93 (Ryukyu Is.: Ohara in Iriomote Is.).

= Ceropria induta (Wiedemann), Castelnau et Brullé, 1831, Ann. Sci. Nat., 23: 399 (Monogr.--Reprint, p. 75) (Java).

Spec. cxam.: 1 sp. (S), Hatsuno, Amami-Oshima, 25. v. 1960, T. Shibata leg.; 1 sp. (S), Takarajima, Tokara Is., 3. vii. 1960, Y. Hama leg.; 3 spp. (CFSRKU), Ohara, Iriomote Is., 8 18. viii. 1962, M. T. Chûjô leg.; 1 sp. (CFSRKU), Ushikumori, Iriomote Is., 2. vii. 1963, Y. Miyatake leg.; 6 spp. (J-US), Shirahama, Iri omote Is., 3. x. 1963, S. Uéno leg.; 1 sp. (J-US), Shirahama, Iriomote Is., 4. x. 1963, K. Morimoto leg.; 1 sp. (J-US), Ushikumori, Iriomote Is., 11. x. 1963, S. Kuniyoshi leg.; 3 spp. (J-US), Shirahama, Iriomote Is., 12. x. 1963, S. Uéno \& K. Morimoto leg.; 15 spp. (J-US), Omotodake, Ishigaki Is., 29. x. 1963, Y. Hirashima leg.; 1 sp. (J-US), Shirahama 3 m., Iriomote Is., 2. xi. 1963, G. A. Samuelson leg.; 2 spp. (J-US), Shirahama 3 m., Iriomote Is., 7. xi. 1963, G. A. Samuelson leg. ; 2 spp. (J-US), Mt. Omoto 526 m., Ishigaki Is., 17. xi. 1963, G. A. Samuelson leg.; 1 sp. (J-US), Ushikumori, Iriomote Is., 9. iii. 1964, Y. Miyatake leg.; 1 sp. (J-US), Izumi-Gogayama, Okinawa Is., 22. iii. 1964, C. M. Yoshimoto leg.

Distr.: India, Ceylon, Andaman, Burma, Thailand, Viet-Nam, China, Hainan, Formosa, Philippines, Malacca, Singapore, Celebes, Sumatra, Nias, Java, Simalur, Borneo, Palawan, Halmahera, Japan (Honshu, Shikoku, Kyushu \& Tsushima Is.) and Ryukyu Is. (Tokara Is., Iriomote Is. \& Ishigaki Is.*).

Notes: Castelnau and Brullé (1831) was seemed to place C. induta in the wrong section from the standpoint of the current knowledge of the taxonomy of the Tenebrionidae. When $\mathrm{H}$. Gebien listed C. induta in his catalogue (1911 \& 1940), he adopted Castelnau and Brullés record with some doubt. In 1925, however, he criticized the abovementioned Castelnau and Brullé's opinion as follows: = Castelnau et Brullé haben, wie schon Harold ausführt, unter induta Wiedemann möglichweise irgend eine andere Art verstanden. Aber ihre Beschreibung wiedersplicht doch nicht geradzu der Deutung auf induta Wiedemann im Sinne Harold's."

\section{Addia latior Nakane}

Addia latior Nakane, 1963, Fragm. Col., (7): 27 (Amami-Oshima: Hatsuno \& Shinmura; 1963, Iconogr. Ins. Japonicorum, Colore nat. edt. 2 (Col.): 226, P1. cxiii, Fig. 19 (Amami-Oshima).

Spec. exam.: 1 sp. (J-US), Yuwandake 300-600 m., Amami-Oshima, 29. vii. 1963, J. L. Gressitt leg.; 2 spp. (J US), Yuwandake, Amami-Oshima, 30. vii. 1963, Y. Hirashima leg.; 1 sp. (J-US), Yuwandake, Amami-Oshima, 6. viii. 1963, T. Okada leg.; 2 spp. (J-US), Yona 100 m., Okinawa Is., 27. xi. 1963, G. A. Samuelson leg.; 1 sp. (J-US), Izumi-Gogayama, Okinawa Is., 22. iii. 1964, C. M. Yoshimoto leg.

Distr.: Ryukyu Is. (Amami-Oshima \& Okinawa Is.*). 


\section{Pentaphyllus philippinensis Kaszab}

Pentaphyllus philippinensis Kaszab, 1956, Ann. hist.-nat. Mus. Hungary (N. S.), 7 : 94 (Philippines).-Kaszab, 1964, Ent Rev. Japan, $16(2): 41$ (Tokara Is.: Nakanoshima).

= Pentaphyllus tokarensis Nakane, 1963, Fragm. Col., (7): 27 (Tokara Is.: Takarajima \& Nakanoshima); 1963, Iconogr. Ins. Japonicorum, Colore nat. edit. 2 (Col.): 226, Pl. cxiii, Fig. 21 (Tokara Is.: Nakanoshima).-Kaszab, 1964, Ent. Rev. Japan, 16 (2): 40 \& 41 (new synonym).

Spec. exam.: 1 sp. (C), Nakanoshima, Tokara Is., 5. vii. 1960, M. Sato leg.

Distr.: Philippines and Ryukyu Is. (Tokara Is.).

\section{Subfamily Leiochrinae Lewis, 1894}

\section{Derispia japonica Kaszab}

Derispia japonica Kaszab, 1961, Acta Zool., Acad. Sci. Hungaricae, 7 (12): 160 (Key) \& 181, Figs. 42, 43 \& 46 (Luchu-Insel: Okinawa).

=Derispia amamiana Miyatake, 1961, Trans. Shikoku Ent. Soc., 7 (1-2): 34 (Key) \& 37-38, Figs. 3 \& 7 (Amami-Oshima: Shinmura, Ikari \& Hatsuno).-Kaszab, 1964, Ent. Rev. Japan, 16 (2): 42 (new synonym).

Spec. exam.: 1 sp. (J-US), Yuwan-dake 300-600 m., Amami-Oshima, 29. vii. 1963, J. L. Gressitt leg.; 2 spp. (J-US), Yuwan, Amami-Oshima, 29-31. vii. 1963, Y. Hirashima leg.; 4 spp. (J-US), Yuwandake, Amami-Oshima, 31. vii. 1963, Y. Hirashima leg.; 1 sp. (J-US), Yuwan-dake, Amami-Oshima, 6 viii. 1963, T. Okada leg.; 3 spp. (J-US), Nakaragawa, Iriomote Is., 5. x. 1963, K. Morimoto leg.; 1 sp. (JUS), Yoshiwara, Ishigaki Is., 15. x. 1963, K. Morimoto leg.

Distr.: Ryukyu Is. (Amami-Oshima, Okinawa Is., Ishigaki Is.* \& Iriomote Is.*).

\section{Derispia klapperichi Kaszab}

Derispia shibatai Chûjô et Miyatake, 1961, Trans. Shikoku Ent. Soc., 7 (1-2); 35 (Key) \& 38-39, Figs. 4, 8 \& 9 (Amami-Oshima: Hatsuno).-Kaszab, 1964, Ent. Rev. Japan, 16 (2): 42 (vide nota!).

Spec. exam.; 1 sp. (J-US), Nakijin, Oinawa Is., 12. iv. 1964, T. Takara leg.

Distr.: Ryukyu Is. (Amami-Oshima \& Okinawa Is.*).

Notes: a) So far as the coloration is concerned, Derispia klapperichi (described originally from Fukien Province in S. China) seems to be a variable species. Z . Kaszab (1961) published the following description on the coloration of this species: "Halsschild einfarbig schwarz. Flügeldecken rot mit grossen schwarzen Flecken: 1 Basalmakel in der Mitte, 1 gemeinsamer Schildchenfleck, 1 gemeinsamer Suturalfleck hinter der Mitte, ausserdem die Naht und der Seitenrand, sowie 1 Scheibenfleck in der Mitte schwarz (ab. separata ab. nov.), oder der Scheibenfleck und der mittlere Marginalfleck miteinander verbunden (forma typica), oder wie die vorige, aber der Scheibenfleck vorne mit dem Scutellarfleck, hinten mit dem Suturalfleck verbunden (ab. con- 
fluentissima ab. nov.).-L.: 2.6-2.8 mm. China (Fukien) klapperichi Kaszab, 1946"

If the description and three figures shown in his paper are compared with D. shibatai, it is not difficult to consider that D. kalpperichi and D. shibatai are the same species. I agree with Kaszab's opinion (loc. cit. 1964).

b) Some specialists have the opinion that it is unsuitable to place this group (tribe Leiochrini) in the family Tenebrionidae. But I can not agree with their opinion, because there is no reason to exclude this tribe from the present family from the structural characters of antennae, front coxal cavitaties, tarsus, metendosternite, wing venation and so on $\cdots \cdots$.

\section{Subfamily Phrenapatinae Lacordaire, 1859}

\section{Tagalus tokaranus Nakane}

Tagalus tokaranus Nakane, 1963, Fragm. Col., (7): 28 (Tokara Is.: Nakanoshima); 1963, Iconogr. Ins. Japonicorum, Colore nat. edit. 2 (Col.): 226, Pl. cxiii, Fig. 24 (Tokara Is.: Nakanoshima).

Spcc. exam.: 6 spp. (J-US), Sonai, Iriomote Is., 9. x. 1963, K. Morimoto leg.; 1 sp. (J US), Omotodake, Ishigaki Is., 16. iii. 1964, C. M. Yoshimoto \& J. Harrell leg.

Distr.: Ryukyu Is. (Tokara Is., Ishigaki Is.* \& Iriomote Is.*).

\section{Subfamily Ulominae LeConte, 1862}

\section{Gnathocerus cornutus Fabricius}

Gnathocerus cornutus Fabricius, 1798, Ent. Syst. Supple.: 51.

= cucullatus Montrousier, 1860, Ann. Soc. Ent. France, 8 (3): 294.

- lacviusculus Stephens, 1832, I11. Brit., 5: 10.

= maxillaris Beauv., 1805, Ins. Afr. et Am.; 125, t. 32, f. 4.

$=$ rubor Thunberg, Vetensk. Acad. Handdl.: 17, t. 4, f. A. F. \& 9.

Spcc. cxam: 1 sp. (KU), Naze, Amami-Oshima, 12. vii. 1933, T. Esaki \& K. Yasumatsu leg.

Distr.: Cosmopolitan \& Ryukyu Is. (Amami-Oshima*).

\section{Tribolium (Tribolium) castaneum (Herbst)}

Colydium castaneum Herbst, 1797, Natursyst. Ins. Käfer, 7: 282, P1. cxii, Fig. 13 (Europe).

Tribolium castancum (Herbst), MacLeay, 1825, Annul. Javanica: 47 (Java).

Tribolium (Tribolium) castaneum (Herbst), Gebien, 1940, Kat. Tenebr., 2: (507) (Cosmopolitan).

= Tribolium ferrugineum (Fabricius), Marseul, 1876, Ann. Soc. Ent. France, 6 (5): 112 (Japan: Kiu-Siu). 
Spec. exam.: 2 spp. (S), Santaro pass, Amami-Oshima, 19. v. 1960, T. Shibata leg.; 2 spp. (S), Ikari, Amami-Oshima, 4. vi. 1960. T. Shibata leg.; 1 sp. (J-US), Shirahama, Iriomote Is., 2. xi. 1963, G. A. Samuelson leg.

Distr.: Cosmopolitan; Japan (Honshu, Shikoku \& Kyushu) and Ryukyu Is (Okinawa Is., Amami-Oshima \& Iriomote Is.*).

\section{Cneocnemis laminipes Gebien}

Cneocnemis laminipes Gebien, 1913, Arch. f. Naturg., 79 A (9): 26, f. 27, t. 1, 1. 6 (Formosa).-Nakane, 1963, Iconogr. Ins. Japonicorum, Colore nat. edit. 2 (Col.): 227, Pl. cxiv, Fig. 7 (Japan: Kyushu; Yakushima \& Formosa).

Spec. exam.: 1 sp. (BM), Ishigaki Is., xi-xii. 1952, G. E. Bohart leg.; 1 sp. (KU), Ishigaki city, Ishigaki Is., 28-29. viii. 1958. T. Hidaka leg.; 2 spp. (CFSRKU), Ohara, Iriomote Is., 27 31. viii. 1962, M. T. Chûjô leg.

Distr.: Formosa, Japan (Kyushu) \& Ryukyu Is. (Yakushima, Ishigaki Is.* \& Iriomote Is.*).

\section{Uloma excisa excisa Gebien}

Uloma excisa Gebien, 1913, Arch. f. Naturg., 79, A (9): 24-25, Fig. 7 (Formosa: Tainan, Pilum, Chip-Chip, Kôsempo, Polisha, Sokutsu \& Arisan).-M. T. Chûjô, 1963, Rep. Comm. Foreign Sci. Res., Kyushu Univ., 1: 93-94 (Ryukyu Is.: Ohara \& Shirahama in Iriomote Is.). Kaszab, 1964, Ent. Rev. Japan, 16 (2): 11 (Tokara Is. : Nakanoshima).

Ulomae excisa excisa Nakane, 1956, Sci. Rep. Saikyo Univ., 2 (3): A 167, Pl. ii, Fig. 25 (Tokara Is.: Nakanoshima); 1963, Iconogr. Ins. Japonicorum, Colore nat. edit. 2 (Col.) : 227, Pl. cxiv, Fig. 9 (Nansei Is.).

Spec. exam.: 1 sp. (BM), Chiguka, Okinawa Is., 2. ix. 1945, J. L. Gressitt leg.; 5 spp. (KU), Ishigaki city, Ishigaki Is., 28-29. viii. 1958, T. Hidaka leg.; 3 spp. (S), Ikari, Amami-Oshima, 6. v. 1960, T. Shibata leg.; 1 sp. (S), Ikari, Amami-Oshima, 28. v. 1960, T. Shibata leg.; 1 sp. (S), Ikari, Amami-Oshima, 29. v. 1960, T. Shibata leg. ; 1 sp. (KU), Ohara, Iriomote Is., 22. xi. 1960, K. Yasumatsu leg. ; 4 spp. (CFSRKU), Otomi, Iriomote Is., 12 13. viii. 1962, M. T. Chûjô leg.; 5 spp. (CFSRKU), Shirahama, Iriomote Is., 21-23. viii. 1962, M. T. Chûjô leg.; 1 sp. (CFSRKU), Upper Uraucni Riv., Iriomote Is., 7. vii. 1963, Y. Miyatake leg.; 2 spp. (J-US), Ohara, Iriomote Is., 2. x. 1963, S. Uéno leg.; 2 spp. (J US), Ohara Iriomote Is., 3. x. 1963, S. Uéno leg.; 1 spp. (J US), Shirahama, Iriomote Is., 4. x. 1963, K. Morimoto leg.; 1 sp. (J US), Omotodake, Ishigaki Is., 10. x. 1963, Y. Hirashima leg.; 1 sp. (J-US), Izumi-Gogayama, Okinawa Is., 22. iii. 1964, C. M. Yoshimoto leg.; 2 spp. (J.US), Hentona, Okinawa Is., 25. iii. 1964, C. M. Yoshimoto leg.

Distr.: Formosa and Ryukyu Is. (Tokara Is., Iriomote Is. \& Ishigaki Is.*).

\section{Uloma ichoi Nakane}

Uloma ichoi Nakane, 1956, Sci. Rep. Saikyo Univ., 2 (3): A 168-169, P1. ii. Fig. 30 (Amami-Oshima); 1963, Iconogr. Ins. Japonicorum, Colore nat. edit. 2 (Col.): 227, Pl. cxiv, Fig. 11 (Amami-Oshima).-Kaszab, 1961, Ent. Rev. Japan, 16 (2): 42 (Amami-Oshima: Ikari \& Shinmura).

Spec. exam.: 1 sp. (BM), Ishigaki Is., xi xii. 1952, G. E. Bohart leg.; 1 sp. (KU), Yuwan-Shinmura, Amami-Oshima, 22. vii. 1954, S. Miyamoto \& Y. Hirashima leg. ; 1 sp. (KU), Shinmura, Amami-Oshima, 23. vii. 1954, S. Miyamoto \& Y. Hirashima 
leg.; 1 sp. (S), Naze, Amami-Oshima, 5. v. 1960, T. Shibata leg.; 1 sp. (S), Naze, Amami-Oshima, 15. v. 1960, T. Shibata leg.; 1 sp. (KU), Ohara, Iriomote Is., 22. xi. 1960, K. Yasumatsu leg.; 1 sp. (CFSRKU), Ohara, Iriomote Is., 8 18. viii. 1962, M. T. Chûjô leg.; 2 spp. (KU), Hatsuno, Amami-Oshima, 11. xi. 1962, Y. Miyatake leg.; 1 sp. (J-US), Yuwandake $550 \mathrm{~m}$., Amami-Oshima, 18. vii. 1963, Yoshimoto \& J. Harrell leg.; 2 spp. (J-US), Ohara, Iriomote Is., 2. x. 1963, S. Uéno leg.; 1 sp. (J-US), Nakaragawa, Iriomote Is., 5. x. 1963, K. Morimoto leg.; 3 spp. (J-US), Izumi-Gogayama, Okinawa Is., 22. iii. 1964, C. M. Yoshimoto \& J. Harrell leg.

Distr.: Ryukyu Is. (Amami-Oshima \& Iriomote Is.*).

\section{Alphitobius diaperinus (Panzer)}

Tenebrio diaperinus Panzer, 1797, Faunae Ins. Germaniae, 37: 16 (Germany).

Alphitobius diaperinus (Panzer), Marseul, 1876, Ann. Soc. Ent. France, 6 (5): 112 (Japan: Kiusiu).--Nakane, 1963, Iconogr. Ins. Japonicorum, Colore nat. edit. 2 (Col.): 227, Pl. cxiv, Fig. 12 (Japan: Honshu, Shikoku \& Kyushu; Nansei Is.).

Spec. exam.: None.

Disir.: Cosmopolitan; Japan (Honshu, Shikoku \& Kyushu) and Ryukyu Is.

\section{Alphitobius laevigatus (Fabricius)}

Opatrum laevigatum Fabricius, 1781, Spec. Ins., 1: 90 (Neu-Seeland).

Akis laevigata Fabricius, 1801, Syst. Eleuth., 1: 137 (India orientali).

Hyperops laevigatus (Fabricius), Kraatz, 1865, Revis. Tenebr.: 235 (Vorder-Indien).

Alphitobius lacvigatus (Fabricius), Miwa, 1931, Trans. Nat. Hist. Soc. Formosa, 21

(116): 301 (Formosa: Hori).-Nakane, 1963, Iconogr. Ins. Japonicorum, Colore nat. edit. 2 (Col.): 228, Pl. cxiv, Fig. 13 (Japan: Honshu, Shikoku \& Kyushu; Nansei Is.)-Kaszab, 1964, Ent. Rev. Japan, 16 (2): 41 (Tokara Is.: Nakanoshima).

= Alphitobius piceus (Olivier), Marseul, 1876, Ann. Soc. Ent. France, 6 (5): 112 (Japan).

Spec. exam.: 1 sp. (CFSRKU), Nagahama, Iriomote Is., 20-21. viii. 1962, M. T. Chûjô leg.; 1 sp. (CFSRKU), Shirahama, Iriomote Is., 27. vii. 1963, Y. Miyatake leg.

Distr.: Cosmopolitan; Japan (Honshu, Shikoku \& Kyushu) and Ryukyu Is. (Tokara Is. \& Iriomote Is.*).

\section{Alphitobius nitidulus (Motschulsky)}

Heterophaga nitidula Motschulsky, 1859, Études Ent., 8: 100-102 (Ceylon).

Alphitobius nitidulus (Motschulsky), Fairmaire, 1897, Bull. Soc. Ent. France: 69 (Ryukyu: Ishigaki-Shima).

Spec. exam.: None.

Distr.: Ceylon and Ryukyu Is. (Ishigaki Is.).

\section{Leptoscapha unifasciata Kaszab}

Leptoscapha unifasciata Kaszab, 1964, Ent. Rev. Japan, 16 (2): 47-48 (Amami-Oshima: Ikari).

Spec. exam.: 1 sp. (holotype) (S), Ikari, Amami-Oshima, 22. v. 1960, T. Shibata leg.; 1 sp. (paratype) (S), Ikari, Amami-Oshima, 30. vi. 1960, T. Shibata leg.; 2. 
spp. (CFSRKU), Goza, Iriomote Is., 14. viii. 1962, M. T. Chûjố leg.; 13 spp (CFSRKU), Shirahama, Iriomote Is., 21-23. viii. 1962, M. T. Chûjô leg.

Distr.: Ryukyu Is. (Amami-Oshima \& Iriomote Is.*).

\section{Eutochia lateralis (Boheman)}

Alphitophagus lateralis (nec Motschulsky, 1859) Boheman, 1858, Frag. Eugenies Resa, Zool. 4: 94 (Hongkong).

Eutochia lateralis (Boheman), Fairmaire, 1893, Ann. Soc. Ent. France, 12: 20 (Japan) -Nakane, 1963, Iconogr. Ins. Japonicorum, Colore nat. edit. 2 (Col.): 228, P1 cxiv, Fig. 15 (Japan: Yakushima; Takarajima \& Nakanoshima).

=Holaniara picescens Fairmaire, 1885, Ann. Soc. Ent. Balgique, Compt.-Rend. cix. (Sumatra or Borneo).

Spec. exam.: 1 sp. (J US), Shirahama, Iriomote Is., 6. x. 1963, K. Morimoto leg.; 1 sp. (J-US), Sonai, Iriomote Is., 6. x. 1963, S. Uéno leg.; 1 sp. (J-US), Sonai, Iriomote Is., 8. x. 1963, K. Morimoto leg.; 1 sp. (J US), Sonai, Iriomote Is., 12. x. 1963, K. Morimoto leg.

Distr.: From India to Philippines; Formosa, Ryukyu Is. (Tokara Is. \& Iriomote Is.*), Japan (Yakushima), S. Mariana Is. and Hawaii Is.

\section{Hypophloeus (Paraphloeus) amamiensis Kaszab}

Hypophloeus (Paraphloeus) amamicnsis Kaszab, 1964, Ent Rev. Japan, 16 (2): 48-49 (Amami-Oshima: Kominato).

Spec. exam.: 2 spp. (holotype and paratype)(S), Kominato, Amami-Oshima, 29 v. 1960, K. Yamada leg.; 1 sp. (CFSRKU), Shirahama, Iriomote Is., 21 23. viii 1962, M. T. Chûjô leg.; 6 spp. (J US), Yoshiwara, Ishigaki Is., 15. x. 1963, K Morimoto leg.

Distr.: Ryukyu Is. (Amami-Oshima, Ishigaki Is.* \& Iriomote Is.*).

\section{Hypophloeus (Paraphloeus) gentilis (Lewis)}

Corticeus gentilis Lewis, 1894, Ann. Mag. Nat. Hist., (6), 13 (77): 468 (Japan: Yokohama).

Hypophloeus gentilis (Lewis), Gebien, 1911, Junk-Schenkling's Col. Cat., 28: 414 (Japan).

Hypophloous (Paraphloeus) gentilis (Lewis), Gebien, 1940, Kat. Tenebr., 2: (599) (Japan, Formosa, Tonkin \& India).

=Hypophloeus robustus Gebien, 1913, Arch. f. Naturg., 79, A (9): 29 (Formosa . Suisharyo).-Nakane, 1963, Iconogr. Ins. Japonicorum, Colore nat. edit. 2 (Col.) 228, Pl. cxiv, Fig. 19 (Tokara Is.: Nakanoshima).

Spec. exam.: 1 sp. (CFSRKU), Shirahama, Iriomote Is., 21-23. viii. 1962, M. T. Chûjô leg.

Distr.: Japan (Honshu), Ryukyu Is. (Tokara Is. \& Iriomote Is.*), Formosa, Tonkin and India.

\section{Subfamily Tenebrioninae Redtenbacher, 1845}

\section{Setenis oshimanus Miwa}

Setenis oshimanus Miwa, 1935, Trans. Kansai Ent. Soc., (6): 21-22, Pl. ii, Fig. 1 
(Oshima: Gusuku).-Gebien, 1911, Kat. Tenebr., 2: (643) (Amami-Oshima).Nakane, 1963, Iconogr. Ins. Japonicorum, Colore nat. edit. 2 (Col.): 229, P1. cxv, Fig. 4 (Amami-Oshima).

Spec. cxam.: 1 sp. (J-US), Mikyo 200 m., Tokunoshima, 27. vii. 1963, J. L. Gressitt leg.

Distr.: Ryukyu Is. Tokunoshima* \& Amami-Oshima).

\section{Menephilus arciscelis Marseul}

Mcnephilus arciscelis Marseul, 1876, Ann. Soc. Ent France, 6 (5): 119-120 (Japan). - Nakane, 1963, Iconogr. Ins. Japonicorum, Colore nat. edit. 2 (Col.): 228, Pl. cxiv, Fig. 20 (Japan: Honshu, Shikoku \& Kyushu; Amami-Oshima).-Kaszab, 1964, Ent. Rev. Japan, 16 (2): 41 \& 42 (Tokara Is. : Nakanoshima ; Amami-Oshima: Sakibaru, Shinmura \& Naze).

Spec. cxam.: 2 spp. (KU), Naze, Amami-Oshima, 12. vii. 1933, T. Esaki \& K. Yasumatsu leg.: 1 sp. (KU), Santarô-tôge, Amami-Oshima, 15. vii. 1945, G. E. Bohart leg.; 1 sp. (KU), Hatsuno, Amami-Oshima, 11. xi. 1962, Y. Miyatake leg.; 1 sp. (J US), Yuwandake 550 m., Amami-Oshima, 17. vii. 1963, C. M. Yoshimoto leg. ; 1 sp. (J US), Yuwandake 300-600 m., Amami-Oshima, 29. vii. 1963, J. L. Gressitt leg.; 1 sp. (J-US), Kametsu, Tokunoshima, 11. viii. 1963, T. Okada leg.

Distr.: Ryukyu Is. (Amami-Oshima, Tokara Is. : Nakanoshima \& Tokunoshima*) and Japan (Honshu, Shikoku \& Kyushu).

\section{Tenebrio obscurus Fabricius}

Tcnebrio obscurus Fabricius, 1792, Ent. Syst., 1: 111 (Germania).-Nakane, 1963, Iconogr. Ins. Japonicorum, Colore nat. edit. 2 (Col.): 228, Pl. cxiv, Fig. 22 (Japan: Hokkaido, Ionshu, Shikoku \& Kyushu; Nansei Is.).

Tonebrio (Tenebrio) obscurus Fabricius, Reitter, 1911, Fauna Germanica, 3: 347 Deutschlands).

Spcc. exam.: None.

Dist.: Cosmopolitan; Japan (Hokkaido, Honshu, Shikoku \& Kyushu) and Ryukyu Is.

\section{Toxicus funginum Lewis}

Toxicum funginum Lewis, 1894, Ann. Mag. Nat. Hist., (6), 13 (77) : 469 (Japan: Ichiuchi, Nara and near the lake of Ogura)-M. T. Chûjô, 1963, Rep. Comm. Foreign Sci. Res., Kyushu Univ., 1: 94 (Ryukyu Is.: Shirahama in Irimote Is.).

--Toxicum cavifrons Pic, 1913, Mél. Exot.-Ent., 6: 17 (Formosa: Tainan).

Spec. cxam.: 1 sp. (CFSRKU), Shirahama, Iriomote Is., 21-23. viii. 1962, M. T. Chûjô leg.

Distr.: Formosa; Japan (Honshu \& Kyushu) and Ryukyu Is. (Iriomote Is.).

\section{Cryphaeus punctulatus (Lewis)}

Anthracias punctulatus Lewis, 1894, Ann. Mag. Nat. Hist., (6), 13 (77): 470-471 (Japan: Oyayama, Oguma and Goka in Kumakuni).

Cryphacus punctulatus (Lewis), Gebien, 1941, Kat. Tenebr., 2: (665) (Japan).-Nakane, 1963, Iconogr. Ins. Japonicorum, Colore nat. edit. 2 (Col.): 229, Pl. cxv, Fig. 10 (Japan: Kyushu; Tokara Is.: Nakanoshima). 
Spec. exam.: None.

Distr.: Japan (Kyushu) and Ryukyu Is. (Tokara Is.).

\section{Cryphaeus satoi Kaszab}

Cryphaeus satoi Kaszab, 1964, Ent. Rev. Japan, 17 (1): 1-2 (Tokara Is.: Nakanoshima; Amami-Oshima: Ikari).

Spec. exam.: 2 spp. (CFSRKU), Ushikumori, Iriomote Is., 2. vii. 1963, Y. Miya. take leg.; 3 spp. (J-US), Mt. Omoto 100-250 m., Ishigaki Is., 29. x. 1963, G. A. Samuclson leg.

Distr.: Ryukyu Is. (Tokara Is., Amami-Oshima, Ishigaki Is.* \& Iriomote Is.*).

\section{Subfamily Cnodaloninae Lacordaire, 1859}

\section{Tetraphyllus amamiensis Kaszab}

Tetraphyllus amamiensis Kaszab, 1964, Ent. Rev. Japan, 17 (1): 2-3 (Amami-Oshima : Hatsno).

Spec. exam.: 2 spp. (holo- and paratype) (S), Hatsuno, Amami-Oshima, 25. v* 1960. T. Shibata leg.

Distr.: Ryukyu Is. (Amami-Oshima).

\section{Hemicera alternata nodokai Nakane}

Hemicera nodokai Nakane, 1963, Fragm. Col., (7): 28 (Amami-Oshima); 1963, Iconogr. Ins. Japonicorum, Colore nat. edit. 2 (Col.): 230, Pl. cxv, Fig. 14 (AmamiOshima).

Hemicera alternata nodokai Nakane, Kaszab, 1964, Ent. Rev. Japan, 17 (1): 3 (Amami-Oshima: Ikari).

Spec. exam.: 1 sp. (S), Ikari, Amami-Oshima, 6. v. 1960, T. Shibata leg.

Distr.: Ryukyu Is. (Amami-Oshima).

Note: This subspecies was described by T. Nakane (1963) as an independent species, but later $Z$. Kaszab regarded this a subspecies of H. alternata Gebien, 1913, Arch. f. Naturg., 79, A (9) : 37 (Formosa). I agree with Kaszab's opinion.

\section{Hemicera fukiensis Kaszab}

Hemicera fukiensis Kaszab, 1951, Ann. hist.-nat. Mus. Hungary (N. S.), 5 : 258 (China : Fukien); 1964, Ent. Rev. Japan, 16 (2): 42 (Amami-Oshima: Ikari \& Santaro. Pass).

Spec. exam.: 1 sp. (S), Ikari, Amami-Oshima, 21. v. 1960, T. Shibata leg.; I sp. (S), Ikari, Amami-Oshima, 28. v. 1960, T. Shibata leg.; 1 sp. (J-US), Yuwandake 550 m., Amami-Oshima, 16. vii. 1963, C. M. Yoshimoto leg.; 2 spp. (J-US), Yuwandake, Amami-Oshima, 31. vii. 1963, Y. Hirashima leg.

Distr: China and Ryukyu Is. (Amami-Oshima). 


\section{Hemicera multicolor (Fairmaire)}

Eucyrtus multicolor Fairmaire, 1893, Notes Leyden Mus., 14: 40 (Borneo).--Miwa 1933, Trans. Nat. Hist. Soc. Formosa, 23 (124): 9 (Loo-Choo: Iriomote Is.).

Hemicera multicolor (Fairmaire), Gebien 1941, Kat. Tenebr., 2: (700) (Borneo; transferred from the genus Eucyrtus to the genus Hemicera).

Spec. exam.: 1 sp. (CFSRKU), Shirahama, Iriomote Is., 27. vii. 1963, Y. Miyatake leg.; 1 sp. (J-US), Yoshiwara, Ishigaki Is., 15. x. 1963, K. Morimoto leg.; 1 sp. (J-US), Izumi, Okinawa Is., 21. x. 1963, S. Uéno leg.

Distr.: Borneo and Ryukyu Is. (Iriomote Is., Ishigaki Is.* \& Okinawa Is.*).

\section{Phaedis (Phaedis) helopioides Pascoe}

Gnesis helopioides Pascoe, 1866, Journ. Ent., 2: 477 (Manchuria).

Phacdis (Phaedis) helopioides (Pascoe), Gebien, 1941, Kat Tenebr., 2: (705) (Indochina \& Japan).

Phacdis helopioides Marseul, Nakane, 1963, Iconogr. Ins. Japonicorum, Colore nat. edit. 2 (Col.): 230, Pl. cxv, Fig. 17 (Japan: Honshu, Shikoku \& Kyushu; For. mosa).

Phacdis helopioides Pascoe, „Kaszab, 1964, Ent. Rev. Japan, 16 (2): 41 \& 42 (Tokara Is.: Takarajima; Amami-Oshima: Shinmura \& Naze).

=Tromostermus Haagi Harold, 1876, Abh. Ver. Bremen, 5: 131 (Japan).

Spcc. cxam.: 1 sp. (KU), Yakkachi, Amami-Oshima, 19. vii. 1933, T. Esaki \& K. Yasumatsu leg.; 1 sp. (S), Ikari, Amami-Oshima, 12. v. 1960, T. Shibata leg.; 1 sp. (S), Shinmura, Amami-Oshima, 15. v. 1960, T. Shibata leg.; 1 sp. (J-US), Izumi, Okinawa, 21. x. 1963, S. Uéno leg.

Distr.: Indo-China, Manchuria, Japan (Honshu, Sado Is., Shikoku \& Kyushu), Ryukyu Is. (Tokara Is., Amami-Oshima \& Okinawa Is.*) and Formosa.

\section{Phaedis (Phaedis) magnipunctatus sp. nov. (PI. II : 4)}

Body convexed, stocky, metallic purple. Head rather transverse, irregularly and roughly punctate; frontal suture visible; frons weakly projecting at the sides. Antennae reaching front coxal cavity, 11 segmented, 7-10 loosely clubbed; 1 thick, 2 shortest, $3=45,4$ a little longer than 5,5 a little longer than $6,4-6$ weakly dilated towards apex, 7 comparatively and strongly dilated towards apex, 8-10 transverse, apical one oblong oval. Maxillary palpus long; 1 very short, 2 longer than 3, 2 and 3 dilated towards apex, 4 typically securiformed. Pronotum transverse, roughly punctate; front moderately curved forwardly; lateral margins weakly and evenly curved outwardly, narrowly marginated; hind margin weakly bisinuate, narrowly marginated with middle part projecting backwardly. Scutellum small, triangle. Elytra nearly fused, widest at middle part, narrowly marginated, striate-punctures large and deep, 1st punctate-stria reduced at $1 / 5$ from base, 2 reaching apex, 3 and 8 meeting together near apex, 4 first united with 5 at $2 / 3$ from base and then with 7 at $1 / 5$ from base, 6 reduced at $5 / 7$ from base. Underside of head with a deep suture between submentum and gular. Prosternum obliquely rugose at the sides; prosternal process very feebly narrowed posteriorly with apex rounded, sparsely punctate on the surface with a short central longitudinal groove. Mesosternum with a V-shaped protuberance to receive prosternal process, very sparsely punctate. Metasternum strongly and roughly punctate, 
with four transverse sutures between middle coxal cavities; metepisternum densely punctate. 1-3 visible abdominal sternites roughly and strongly punctate, 4 and 5 movable, with very scarce punctures. Front coxal cavity rounded; front femur scarcely punctured, with a thick and stout tooth projecting forwardly at $2 / 3$ from base; front tibia slender, weakly curved inwardly, with a tuff of fine golden hairs near apex; front tarsus thick, 1-4 dilated towards apex and cushioned beneath, 1 longer than 2, 2 nearly equal to 3,4 smallest, 5 weakly dilated towards apex, with long hairs beneath; claw simple, bifurcated. Middle coxal cavity rather round; middle femur thickest at $3 / 5$ from base, very sparsely punctate; the shape of middle tibia and tarsi nearly the same as front tibia and tarsus; hind coxal cavity transverse; hind femur with scarce punctures; hind tibia the same as middle tibia; hind femur with scarce punctures; hind tibia the same as middle tibia; hind tarsus with thick hairs, 1-3 strongly dilated towards apex, 1 thickest, 2 smaller than 1,3 smallest, $2+3$ nearly equal to 1 in length. Hind wing completely reduced.

Length: $7.0-8.5 \mathrm{~mm}$. Width: $3.0-3.5 \mathrm{~mm}$.

Distribution: Ryukyu Is. (Ishigaki Is., Iriomote Is. \& Miyako Is.).

Type materials: Holotype 令(J-US), Yoshiwara, Ishigaki Is., 16. x. 1963, S. Uéno leg. Paratypes (BM), 1 ㅇ Hirara, Miyako Is., 23. x. 1952, G. E. Bohart leg.; $1 \hat{\delta}$ (BM), Ishigaki Is., xi-xii. 1952, G. E. Bohart leg.; 1令 (BM), Ishigaki Is., 1-10. xii. 1952, G. E. Bohart leg. ; 3 $\hat{o}$ (BM), Ishigaki Is., 10-15. xii. 1952, G. E. Bohart leg. ; $1 \hat{o}$ (BM), Ishigaki Is., 10-20. xii. 1952, G. E. Bohart leg.; $1 \hat{\delta} \& 1$ 우 (BM), Ishigaki Is., 15-20, xii. 1952, G. E. Bohart leg.; 2 占占 (BM), Ishigaki Is., 20-30. xii. 1952, G. E. Bohart leg.; 1 우 (J-US), Sonai, Iriomote Is., 6. x. 1963, K. Morimoto leg.; 2 令 \& 1 우(J-US), Sonai, Iriomote Is., 9. x. 1963, S. Kuniyoshi leg.; 2 qㅜ (J-US), Yoshiwara, Ishigaki Is., 15. x. 1963, K. Morimoto leg.

This species is related to $P$. (P.) helopioides (Pascoe), but easily distinguished from the latter by the following characters: elytral striate-punctures much larger and deeper, with interval more separated, tooth of front femur larger.

\section{Obriomaia palpalis palpaloides Nakane}

Obriomaia palpaloides Nakane, 1963, Fragm. Col., (7): 28 (Tokara Is.: Nakanoshima); 1963, Iconogr. Ins. Japonicorum, Colore nat. edit. 2 (Col.): 230, Pl. cxv, Fig. 19 (Nansei Is.).

Obriomaia palpalis palpaloides Nakane, Kaszab, 1964, Ent. Rev. Japan, 16 (2): 12 \& 17 (1) : 3-4 (Tokara Is. \& Amami-Oshima).

Spec. cxam.: 1 sp. (BM), Okinawa Is. 1951, R. E. Doty leg.; 1 sp. (S), Hatsuno, Amami-Oshima, 27. v. 1960, T. Shibata leg.; 1 sp. (J-US), Nishinakama, AmamiOshima, 19. vii. 1963, T. Shibata leg.; 1 sp. (J-US), Nishinakama, Amami-Oshima, 19. vii. 1963. Y. Miyamoto leg.

Distr.: Ryukyu Is. (Tokara Is., Amami-Oshima \& Iriomote Is.*).

Notes: This subspecies was described by $T$. Nakane as an independent species which is related to $O$. palpalis Kaszab, from Formosa, 1941. But, latter Z. Kaszab (1964) compared and reexamined O. palpaloides (collected in Tokara Is. and Amami-Oshima) with O. palpalis 
described by himself and concluded that the former is a subspecies of the latter.

\section{Obriomaia rufiventris Kaszab}

Obriomaia rufiventris Kaszab, 1964, Ent. Rev. Japan, 17 (1): 4-5 (Amami-Oshima: Ikari \& Mt. Yuwan).

Spec. exam.: 1 sp. (KU), Santaro-toge, Amami-Oshima, 26. vii. 1954, S. Miyamoto \& Y. Hirashima leg.; $1 \mathrm{sp.} \mathrm{(paratype)} \mathrm{(S),} \mathrm{Ikari,} \mathrm{Amami-Oshima,} \mathrm{6.} \mathrm{v.} \mathrm{1960,} \mathrm{T,}$ Shibata leg.; 1 sp. (holotype) (S), Ikari, Amami-Oshima, 17. v. 1960, T. Shibata leg.; 1 sp. (paratype) (S), Yuwan, Amami-Oshima, 1. vi. 1960, T. Shibata leg.; 1 sp. (J-US), Yuwandake 10-300 m.. Amami-Oshima, 29. vii. 1963, J. L. Gressitt leg.; 1 sp. (J-US), Naze, Amami-Oshima, 3. viii. 1963, T. Okada leg.

Distr: Ryukyu Is. (Amami-Oshima).

\section{Pseudonautes purpurivittatus (Marseul)}

Scotacus? purpurivittatus Marseul, 1876, Ann. Soc. Ent. France, 6 (5): 130-131 [Japan: Kiu-Siu (Nagasaki) \& Niphon (Hiogo)].

Scotacus purpurivittatus Marseul, Schönfeldt, 1887, Cat. Col. Japan: 132 (Japan: Hiogo \& Nagasaki).

Thydemus (gen. nov.) purpurivittatus (Marseul), Lewis 1894, Ann. Mag. Nat. Hist., (6), 13 (77): 475-476 (Japan: Nagasaki \& Hiogo).

Pseudonautes purpurivittatus (Marseul), Miwa, 1931, Syst. Cat. Formosan Col.: 161 165 (Formosa: Kôsempo, Sokutsu, Kankau \& Fuhoshô); 1935, Trans. Kansai Ent. Soc., (6): 22 (Oshima: Naze).-Chûjô, 1959, Mem. Fac. Lib. Arts \& Educ., Kagawa Univ., 2 (69): 7 (Loo-Choo: Nago \& Yurudji in Okinawa).--Nakane, 1963, Iconogr. Ins. Japonicorum, Colore nat. edit. 2 (Col.): 230, P1. cxv, Fig. 20 (Japan: Kyushu: Amami-Oshima \& Ryukyu).

Spec. exam.: 1 sp. (KU), Santaro-toge, Amami-Oshima, 15. vii. 1933, T. Esaki \& K. Yasumatsu leg.; 1 sp. (KU), Yakkachi, Amami-Oshima, 18. vii. 1933, T. Esaki \&. K. Yasumatsu leg.; 1 sp. (KU), Bannadake, Ishigaki Is., 1. vii. 1934, T. Esaki leg.; 1 sp. (BM), Okinawa, vi. 1945, G. E. Bohart leg.; 1 sp. (KU), Yuwa-dake, Amami-Oshima, 22. vii. 1954, S. Miyamoto \& Y. Hirashima leg.; 6 spp. (S), Yuwan, Amami-Oshima, 1. vi. 1960, T. Shibata leg.; 1 sp. (CFSRKU), Upper Urauchi Riv., Iriomote Is., 7. vii. 1963, Y. Miyatake leg.; 1 sp. (J-US), Yuwan, Amami-Oshima, 16. vii. 1963, S. Ito leg.; 1 sp. (J-US), Mikyo 200 m., Tokunoshima, 27. vii. 1963, J. L. Gressitt leg.; 7 spp. (J-US), Yuwandake 300-600 m., Amami-Oshima, 29. vii. 1963, Y. Hirashima leg.; 1 sp. (J-US), Yuwan, Amami-Oshima, 31. vii. 1963, Y. Hirashima leg.; 1 sp. (J-US), Yuwan-dake, Amami-Oshima, 6. viii. 1963, T. Okada leg.; 1 sp. (J-US), Yuan-dake, Amami-Oshima, 7. viii. 1963, T. Okada leg.; 3 spp. (J-US), Omoto-dake 100-250 m., Ishigaki Is., 22. v. 1964, J. L. Gressitt leg.; 1 sp. (J-US), Bannadake 70 m., Ishigaki Is., 23. v. 1964, J. L. Gressitt leg.

Distr.: Japan (Honshu \& Kyushu), Ryukyu Is. (Tokunoshima*, Amami-Oshima \& Okinawa) and Formosa.

\section{Campsiomorpha imperialis (Fairmaire)}

Campsiomorpha imperialis Fairmaire, 1903, Ann. Soc. Ent. Belgique, 47 : 15 (Tonkin). Campsiomorpha imperialis (Fairmaire), Miwa, 1933, Trans. Nat. Hist. Soc. Formosa, 
23 (124): 9 (Loo-Choo: Iriomote Is.).-M. T. Chûjô, 1963, Rep. Comm. Foreign Sci. Res., Kyushu Univ., 1: 94 (Ryukyu Is.: Inaba in Iriomote Is.).

Spec. exam.: 1 sp. (KU), Sonai-Urauchi, Iriomote Is., 24. vi. 1934, T. Esaki leg.; 3 spp. (KU), Shika-Omotodake, Ishigaki Is., 30. vi. 1934, T. Esaki leg.; 3 spp. (KU), Bannadake, Ishigaki Is., 1. vii. 1934, T. Esaki leg.; 2 spp. (BM), Ishigaki Is., 28., vii. 1934, J. L. Gressitt leg.; 1 sp. (BM), Iriomote Is., 24. viii. 1934, J. L. Gressitt leg.; 1 sp. (KU), Ishigaki Is., 15. v. 1936, no collector's name; 1 sp. (CFSRKU), Inaba, Iriomote Is., 24. viii. 1962, M. T. Chûjô leg.; 1 sp. (CFSRKU), Ushikumori, Iriomote Is., 2. vii. 1963, Y. Miyatake leg.; 1 sp. (CFSRKU), Upper Urauchi Riv., Iriomote Is., 9. vii. 1963, Y. Miyatake leg.; 2 spp. (CFSRKU), Kamidake, Iriomote Is., 13. vii. 1963, Y. Miyatake leg.; 1 sp. (CFSRKU), Shirahama, Iriomote Is., 28 vii. 1963, T. Miyatake leg.; 1 sp. (J-US), Bannadake 70 m., Ishigaki Is., 20. v. 1964, J. L. Gressitt leg.; 2 spp. (J-US), Omoto Village 100 m., Ishigaki Is., 22. v. 1964, J. L. Gressitt leg.

Distr.: Tonkin and Ryukyu Is. (Iriomote Is. \& Ishigaki Is.*).

\section{Subfamily Adeliinae Lacordaire, 1859}

\section{Laena rotundicollis insularis Kaszab}

Laena rotundicollis insularis Kaszab, 1964, Ent. Rev. Japan, 17 (1): 5-6 (AmamiOshima: Ikari).

Spec. exam.: 1 sp. (holotype) (S), Ikari, Amami-Oshima, 18. v. 1960, T. Shibata leg.

Distr.: Ryukyu Is. (Amami-Oshima).

\section{Subfamily Misolampinae Lacordaire, 1859}

\section{Eucrossoscelis broscosomoides Nakane}

Eucrossoscelis broscosomoides Nakane, 1963, Fragm. Col., (7): 29 (Amami-Oshima: Mt. Yuwan); 1963, Iconogr. Ins. Japonicorum, Colore nat. edit. 2 (Col.): 233, Pl. cxvii, Fig. 8 (Amami-Oshima).-Kaszab, 1964, Ent. Rev. Japan, 16 (2): 13; 17 (1): 8-9 (Amami-Oshima: Ikari).

Spec. exam.: 1 sp. (S), Santaro-toge, Amami-Oshima, 30. v. 1960, T. Shibata leg.; 1 sp. (S), Ikari Amami-Oshima, 4. vi. 1960, T. Shibata leg.

Distr.: Ryukyu Is. (Amami-Oshima).

\section{Misolampomorphus tokarensis (Nakane)}

Misolampidius tokarensis Nakane, 1963, Fragm. Col., (7): 29 (Tokara Is. Nakanoshima); 1963, Iconogr. Ins. Japonicorum, Colore nat. edit. 2 (Col.): 231, Pl. cxvi, Fig. 6 (Tokara Is.: Nakanoshima).

Misolampomorphus tokarensis (Nakane), Kaszab, 1964, Ent. Rev. Japan, 17 (1): 6-7 (Tokara Is.: Nakanoshima).

Spec. exam.: None.

Distr.: Ryukyu Is. (Tokara Is.). 
Subfamily Helopinae Lacordaire, 1862

\section{Tarpela amamiensis Kaszab}

Tarpcla amamiensis Kaszab, 1964, Ent. Rev. Japan, 17 (1) 7-8 (Amami-Oshima : Ikari).

Spec. cxam.: 1 sp. (KU), Shinmura, Amami-Oshima, 4-5. iv. 1954, S. Miyamoto leg. 2 spp. (holo- and paratype) (S), Ikari, Amami-Oshima, 6. v. 1960, T. Shibaia leg.; 1 sp. (paratype) (S), Ikari, Amami-Oshima, 22. v. 1960, T. Shibata leg.

Distr.: Ryukyu Is. (Amami-Oshima).

\section{Tarpela brunnea konoi Nakane}

Tarpela brunnea konoi Nakane, 1963, Fragm. Col., (7): 28 (Tokara Is.: Nakanoshima) 1963, Iconogr. Ins. Japonicorum, Colore nat. edit 2 (Col.): 230, Pl. cxv, Fig. 21b (Tokara Is.: Nakanoshima).

Spec. cxam.: None.

Distr.: Ryukyu Is. (Tokara Is.: Nakanoshima).

\section{Subfamily Amarygminae Lacordaire, 1859}

\section{Amarygmus callichromus Fairmaire}

Amarygmus callichromus Fairmaire, 1897, Bull. Soc. Ent. France: 70 (Loo-Choos: Ishigaki Is.).-Gebien, 1911, Junk-Schenkling's Col. Cat., 28: 576 (Ishigaki).Miwa, 1931, Syst. Cat. Formosan Col.: 166 (Formosa: Kobshun; Loo-Choo: Ishigaki Is.); 1933, Trans. Nat. Hist. Soc. Formosa, 23 (124): (Loo-Choo: Iriomote Is.).-Gebien, 1944, Kat. Tenebr., 3: 847 (Ishigaki).

Spec. exam.: None.

Distr.: Ryukyu Is. (Ishigaki Is. \& Iriomote Is.) and Formosa.

\section{Plesiophthalmus brevipennis Lewis}

Plesiophthalmus brevipennis Lewis, 1896, Ann. Mag. Nat. Hist., (6), 17 (101): 340 (Oshima).-Schönfeldt, 1897, Cat. Col. Japan, 3: 126 (Oshima).-Miwa, 1935, Trans. Kansai Ent. Soc., (6): 22 (Oshima).-Yamazaki, 1964, Ent. Rev. Japan, 17 (1): 25 (Amami-Oshima).

Spec. exam.: 1 sp. (S), Ikari, Amami-Oshima, 22. v. 1960, T. Shibata leg.; 1 sp. (S), Ikari, Amami-Oshima, 4. vi, 1960, T. Shibata leg.

Distr.: Ryukyu Is. (Amami-Oshima).

\section{Plesiophthalmus fuscoaenescens Fairmaire}

Plesiophthalmus fuscoaenescens Fairmaire, 1898, Bull. Soc. Ent. France: 14 (Loochoos: Ishigaki Is.).-Gebien, 1911, Junk-Schenkling's Col. Cat., 28: 583 (Ishigaki).-Miwa, 1931, Syst. Cat. Formosan Col.: 165 (Formosa : Kiirun; Loo-Choo: Ishigaki); 1933, Trans. Nat. Hist. Soc. Formosa, 23 (124): 9 (Loo-Choo: Iriomote Is.)--Gebien, 1943, Kat. Tenebr., 3: 857 (Ishigaki).-Nakane, 1963, Iconogr. Ins. Japonicorum, Colore nat. edit. 2 (Col.): 232 (Ryukyu Is: Ishigaki Is.).

Spec. exam.: 1 sp. (KU), Bannadake, Ishigaki Is., 24. vi. 1934, T. Esaki leg.; 
2 spp. (KU), Sonai-Shirahama, Iriomote Is., 22. vii. 1934, T. Esaki leg.; 1 sp. (KU), Ishigaki Is., 27. vii. 1936, S. Masaki leg.; 1 sp. (CFSRKU), Ushikumori, Iriomote Is., 2. vii. 1963, Y. Miyatake leg.; 2 spp. (CFSRKU), Upper Urauchi Riv., Iriomote Is., 9. vii. 1963, Y. Miyatake leg.; 2 spp. (CFSRKU), Komidake, Iriomote Is. 13. vii. 1963, Y. Miyatake leg.

Distr.: Tonkin \& Ryukyu Is. (Amami-Oshima* \& Ishigaki Is.*).

\section{Subfamily Strongyliinae Lacordaire, 1859}

\section{Strongylium cultellatum Mäklin}

Strongylium cultellatum Mäklin, 1866, Monogr. Strongylium: 345 (453) (Hongkong). -Kaszab. 1964, Ent. Rev. Japan, 16 (2): 41 (Tokara Is.: Takarajima \& Nakanoshima).

Spec. exam.: 2 spp. (S), Takarajima, Tokara Is., 3. vii. 1960, Y. Hama leg.; 2 spp. (J-US), Yuwan-dake 550 m., Amami-Oshima, 18. vii. 1963, C. M. Yoshimoto leg.

Distr.: Hongkong and Ryukyu Is. (Tokara Is.: Takarajima \& Nakanoshima; Amami-Oshima*).

\section{Strongylium marseuli Lewis}

Strongylium marseuli Lewis, 1894, Ann. Mag. Nat. Hist., (6), 13 (77): 481-482 (Japan: Nagasaki)_-Nakane, 1963, Iconogr. Ins. Japonicorum, Colore nat. edit. 2 (Col.): 233, pl. cxvii, Fig. 3 (Japan: Honshu, Shikoku \& Kyushu).

Spec. exam.: 1 sp. (KU), Ishigaki Is., 22. v. 1934, C. Senaha leg.; 2 spp. (S), Ikari, Amami-Oshima, 2. vii. 1961, T. Shibata leg.; 1 sp. (S), Ikari, Amami-Oshima, 3. vii. 1961, T. Shibata leg.; 1 sp. (S), Ikari, Amami-Oshima, 4. vii. 1961, T. Shibata leg.; 1 sp. (J-US), Nishinakama, Amami-Oshima, 19. vii. 1963, T. Yamasaki leg.; 1 sp. (J-US), Yuwandake, Amami-Oshima, 31 viii. 1963, Y. Hirashima leg.

Distr.: Japan (Honshu, Shikoku \& Kyushu) and Ryukyu Is. (Amami-Oshima* \& Ishigaki Is.*).

\section{Strongylium oshimanum Fairmaire}

Strongylium oshimanum Fairmaire, 1897, Bull. Soc. Ent. France: 167 (Oshima Is.). -Gebien, 1911, Junk-Schenkling's Col. Cat., 37: 598 (Liu-Kiu).-Miwa, 1935, Trans. Kansai Ent. Soc., (6): 22 (Oshima).-Gebien, Kat. Tenebr., 3: 868 (LiuKiu).-Ohbayashi, 1962, Ageha, (10): 20, 1 photo-fig. (Amami-Oshima: Hatsuno). - Nakane, 1963, Iconogr. Ins. Japonicorum, Colore nat. edit. 2 (Col.): 232, Pl. cxvi, Fig. 15 (Amami-Oshima).

Spec. exam.: 1 sp. (J-US), Yuwan, Amami-Oshima, 16 vii. 1963, Y. Hirashima leg.; 1 sp. (J-US), Yuwan, Amami-Oshima, 17. vii. 1963, Y. Hirashima leg.; 1 spp. (J-US), Yuwandake 550 m. Amami-Oshima, 17. vii. 1963, C. M. Yoshimoto leg.

Distr.: Ryukyu Is. (Amami-Oshima). 


\section{ON THE SYSTEMATIC POSITION OF TWO KNOWN-SPECIES AND ESTABLISHMENT OF A NEW FAMILY}

\section{A. Luprops sinensis (Marseul) … (Tenebrionidae to Lagriidae)} (Pl. I : $4 \mathrm{a}-4 \mathrm{c})$

Lyprops sinensis Marseul, 1876, Ann. Soc. Ent. France, 6 (5): 126 (Kiu-Siu \& Niphon). Luprops sinensis (Marseul) Gebien, 1941, Kat. Tenebr., 2: (508) (Japan). Kaszab, 1964, Ent. Rev. Japan, 16 (2): 41 (Tsushima Is.: Mt. Ariake-yama; Tokara Is.: Takarajima \& Nakanoshima).

Luprops sinensis (Marseul), Nakane, 1963, Iconogr. Ins. Japonicorum, Colore nat. edit. 2 (Col.): 233, Pl. cxvii, Fig. 11 (Japan: Hokkaido, Honshu, Shikoku \& Kyushu) (as a largriid species).

Spec. exam.: 1 sp. (BM), Ishigaki Is., x. 1951, G. E. Bohart leg.; 2 spp. (KU), Yona, Okinawa Is., 16-18. viii. 1958, T. Hidaka leg.; 3 spp. (KU), Nago, Okinawa, 8. vii. 1961, S. Higashihirachi leg.; 5 spp. (J-US), Yuwan, Amami-Oshima, 29. vii. 1963, Y. Hirashima leg.; 5 spp. (J-US), Omotodake, Ishigaki Is., 1. x. 1963, K. Morimoto leg.; 9 spp. (J-US), Shirahama, Iriomote Is., 4. x. 1963, S. Uéno leg.; 3 spp. (J-SU), Shirahama, Iriomote Is., 4. x. 1963, K. Morimoto leg. 1 sp. (J-US), Omotodake, Ishigaki Is. 10. x. 1963, Y. Hirashima leg.; 9 spp. (J-US), Ushikumori, Iriomote Is., 11. x. 1963, S. Kuniyoshi leg.; 3 spp. (J-US), Omotodake Ishigaki Is., 14 x. 1963, S. Kuniyoshi leg.; 1 sp. (J-US), Minamimeijiyama, Okinawa Is., 20. x. 1963, S. Uéno leg.; 3 spp. (J US), Izumi, Okinawa Is., 21. x. 1963., S. Uéno leg.; 6 spp. (J-US), Kawaradake, Ishigaki Is., 28. x. 1963, Y. Hirashima leg.; 4 spp. (J-US), Shirahama-Sonai, Iriomote Is., 8. iii. 1964, Y. Miyatake leg.; 2 spp. (J-US), Ushikumori, Iriomote Is., 9. iii. 1964, Y. Miyatake leg. ; 2 spp. (J-US), Ushikumori, Iriomote Is., 11. iii. 1964, Y. Miyatake leg.

Distr.: Japan (Hokkaido, Honshu, Shikoku, Kyushu \& Tsushima Is.), Ryukyu Is. (Tokara Is., Amami-Oshima*, Ishigaki Is.* \& Iriomote Is.*), Korea, Formosa and China.

Discussion: Some authorities exclude this species from the Tenebrionidae and transfer it into the Lagriidae, but the other specialists treat this species as a member of the present family. In order to make clear the systematic position of the genus and species in question, I examined many specimens of this species and three lagriid species, Lagria rufipennis Marseul, Arthromacra viridissima Lewis and Nemostria rufobrunnea Marseul. Their penultimate tarsal segments show completely the same structure, viz. the segments not simple but flabellate. On the other hand, a distinct differentiation is recognized in the wing venation. Generally the radial cell is not present in the Tenebrionidae, while this part can be seen in this species and the lagriid species. On the basis of these structural characters, Luprops sinensis (Marseul) may not be a member of the Tenebrionidae, but should be placed in the Lagriidae. At the same time this genus, Luprops, should be transferred to the Lagriidae. 
B. Heterotarsvs crenulifer Kaszab … (Tenebrionidae to Heterotarsidae, fam. nov.) (Pl. I : 5a-5c)

Heterotarsus crenulifer Kaszab, 1941, Stettiner Ent. Zeit., 102: 58-59 (Formosa: Kosmpo).

Spec. exam.: 9 spp. (BM), Hirara, Miyakojima, 23. x. 1952, G. E. Bohart leg.; 1 sp. (BM), Ishigaki Is., 10-15. xi. 1952, G. E. Bohart leg.; 1 sp. (BM), Ishigaki Is., xi-xii. 1952, G. E. Bohart leg.; 4 spp. (BM), Ishigaki Is., 10-15. xii. 1952, G. E. Bohart leg.

Distr.: Formosa and Ryukyu Is. (Miyakojima* \& Ishigaki Is.*).

Discussion: This genus has long been placed in the Tenebrionidae. But, recently some specialists have treated this group as a member of the Lagriidae. R. A. Crowson suggested in his remarkable paper, Nat. Classif. Fam. Col., 1955, p. 126, that Heterotarsini is intermediate between the present family and the Lagriidae. T. Nakane followed the opinion of R. A. Crowson and placed this genus in the Lagriidae in Iconograph [1963, Iconogr. Ins. Japonicorum, Colore nat. edit. 2 (Col.) : 233 \& 234, Pl. cxvii, Fig. 10-12]. But Z. Kaszab treated the subfamily Heterotarsinae as a member of the Tenebrionidae in his recent paper [1964, Ent. Rev. Japan, 16 (2): 39 \& 40]. R. A. Crowson described in the same paper that Heterotarsus incidentally has 4-4-3 tarsi. But the penultimate tarsal segment is too short and cryptic in each leg to be recognized, because it is almost hidden by the pubescence growing on the underside of the flabellate subpenultimate tarsal segment. This fact might have caused the misinterpretation of Crowson on the number of tarsal segments. Apical and penultimate tarsal segments are simple and, beside these, each segment is covered by dense pubescence on the underside. Such special characters are not found in the Tenebrionidae. The radial cell and radial spur are observed in the wing venation of Heterotarsus but these special characters are generally not found in the Tenebrionidae (Strongylium has the same type as this genus.).

I examined the present species and H. carinula Marseul and checked carefully the original descriptions on several species belonging to this genus. This is a type-genus of Heterotarsinae, but as stated above, it seems to be unsuitable to set this genus in the Tenebrionidae. On the other hand, there is no known-family to accept this genus.

Judging from the combined characteristics mentioned above, I would like to exclude the genus Heterotarsus from the Tenebrionidae and to erect a new family, Heterotasidae, for the reception of the genus Heterotarsus placing the new family between the Lagriidae and Zopheridae. 


\section{Literature Cited}

Chûjô, M. 1959. Coleoptera of the Loo-Choo Archipelago, I. Mem. Fac. Lib. Arts \& Educ., Kagawa Univ., 2 (69): 1-15. (Especially p. 7).

Chûjô, M. T. 1963 (June, 20). A new species of Gonocephalum Solier from Okinawa and Takara Is. (Coleoptera, Tenebrionidae). Kontyû, 31 (2): 149-153.

Chûjô, M. T. 1963 (July). Cicindelid, Scarabaeid and Tenebrionid beetles (Coleoptera) from the Yaeyama Group collected by the Kyushu University Expedi. tion. 1st. Rep. Kyushu Univ. Exped. Yaeyama group, Ryukyu (Rep. Comm. Foreign Sci. Res., Kyushu Univ., No. 1): 91-94. (Especially pp. 93-94).

Fairmaire, L. 1897. Descriptions de six Coléoptères de l'île Ishigaki-Sima. Bull. Soc. Ent. France: 68-72. (Especially p. 70).

Fairmaire, L. 1897. Descriptions de deux Coléoptères nouveaux du Japon. Bull. Soc. Ent. France: 166-167.

Fairmaire, L. 1898. Descriptions de trois Coléoptères deslîles Ishigaki (Japon méridional). Bull. Soc. Ent. France: 14-15.

Kaszab, Z. 1952. Die indomalaischen und ostasiatischen Arten der Gattung Gonocephalum Solier (Coleoptera: Tenebrionidae). Ent. Arb. Mus. G. Frey, 3 (2): 416-688, 511 figs. (Especially pp. 454 \& 643-646, Figs. $413-415$; pp. 458 \& 667-668, Figs. 499-503).

Kaszab, Z. 1961 (March). Revision der Tenebrioniden-Gattung Derispia Lewis (Coleoptera). Acta Zool., Acad. Sci. Hungaricae, 7 (1 2): 139-184, 48 figs. (Espially pp. 160 \& 181, Fig. 46).

Kaszab, Z. 1964 (April). Über die Tenebrioniden einiger japanischen Inseln, I (Coleoptera). Ent. Rev. Japan, 16 (2): 39-49.

Kaszab, Z. 1964 (August). Über die Tenebrioniden einiger Japanischen Inseln, II (Coleoptera). Ent. Rev. Japan, 17 (1): 1-10.

Lewis, G. 1896. On new species of Coleoptera from Japan, and notices of others. Ann. Mag. Nat. Hist., (6), 17 (101): 329-343, 2 figs. (Especially p. 340.)

Miwa Y. 1931. A systematic catalogue of Formosan Coleoptera. Dept. Agr. Gov. Res. Inst. Formosa, Japan, Rep. No. 55, pp. I XI, A-B \& 1-359. (Especially 165 \& 166).

Miwa, Y. 1933. An enumeration of Coleoptera from the island Iriomote in Loochoo, with descriptions of new species. Trans. Nat. Hist. Soc. Formosa, 23 (124): 4-15, 3 figs. (Especially p. 9).

Miwa, Y. 1935. Coleoptera from Amami-islands in Loo-Choo Archipelago. Trans. Kansai Ent. Soc., (6): 11-30, P1. III (incl. 19 coloured figs.) \& P1. IV (incl. 28 coloured figs.). (Especially pp. 21 \& 22, P1. III, Fig. 1).

Miyatake, M. 1961. The tribe Leiochrini of Japan (Coleoptera: Tenebrionidae). Trans. Shikoku Ent Soc., 7 (1-2): 33-40, 9 figs. (Especially 34-35 \& 37-39, Figs. $3,4,7,8$ \& 9).

Nakane, T. 1956. New or little-known Coleoptera from Japan and its adjacent regions, XIII. Sci. Rep. Saikyo Univ., 2 (3): A 159-A 174, 35 figs. (Especially p. A 167, Fig. 25; A 168-169, Fig. 30).

Nakane, T. 1963 (May). New or little-known Coleoptera from Japan and its adjacent regions, XIX. Fragm. Col., (6) : 26.

Nakane, T. 1963 (June). New or little-known Coleoptera from Japan and its adjacent regions, XIX (continued). Fragm. Col., (7):27-30, 1 fig. (Especially pp. $27-29)$. 
Nakane, T. 1963 (June 30). Iconographia Insectorum Japonicorum, Colore naturali edita Volumen II: Coleoptera, Hokuryukan Co., Tokyo, 18-443 pp., 192 pls. (Especially pp. 223-233, Pl. CXI, Figs. 4, 14b, 15 \& 17b; Pl. CXII, Figs. 2, 11b \& 20; P1. CXIII, Figs. 6, 14, 19, 21, \& 21 ; Pl. CXIV, Figs. 9, 11, 12, 13, 15, 19, 20 \& 22; Pl. CXV, Figs. 4, 10, 14, 19, 20 \& 21b; P1. CXVI, Figs. 6 \& 15; P1. CXVII, Fig. 8).

Nomura, S. 1964 (December). Some new species of the Coleoptera from Loochoo Is. and its adjacent regions, II. Ent. Rev. Japan, 17 (2): 47-57, 7 text figs., 10 figs. (Especially pp. 48-49).

Ohbayashi, N. 1962. Two rare beetles from Amami-Oshima. Ageha, Matsuyama Insect-Lovers' Assoc. Japan, (10): 20 (2 Photo-figs.). (Especially p. 20, Photofig. 2).

Yamazaki, H. 1964 (August). Plesiophthalmus nigrocyaneum Motschulsky and its allied species from Japan. Ent. Rev. Japan, 17 (1): 19-27, 2 figs. (Especially p. 25).

Yashiro, H. 1927. A list of insects in Roo-Choo islands, No. 1. Okinawa Sugar Exper. Stat., 35 pp. (Especially p. 8).

\section{Explanation of Plate 1}

1a Hind wing of Basanus amamiensis sp. nov. (9.4 mm. in length)

1b Dorsal view of male genitalia of Basanus amamiensis sp. nov. $(1.4 \mathrm{~mm}$. in length)

1c Lateral view of male genitalia of Basanus amamiensis sp. nov.

1d Met-endosternite of Basanus amamiensis sp. nov. (1.6 mm. in length)

2a Hind wing of Basanus tsushimensis M. T. Chûjo ( $9.5 \mathrm{~mm}$. in length)

2b Dorsal view of male genitalia of Basanus tsushimensis M. T. Chûjô $(1.8 \mathrm{~mm}$. in length)

2c Lateral view of male gemitalia of Basanus tsushimensis M. T. Chûjô

2d Met-endosternite of Basanus tsushimensis M. T. Chûjô (1.8 mm. in length)

3a Hind wing of Diphyrrhinchus iriomotensis sp. nov. (5.6 mm. in length)

3b Dorsal view of male genitalia of Diphyrrhinchus iriomotensis sp. nov. $(1.3 \mathrm{~mm}$. in length)

3c Lateral view of male genitalia of Diphyrhinchus iriomotensis sp. nov.

3d Met-endosternite of Diphyrrhinchus iriomotensis sp. nov. (1.0 mm. in length)

4a Hind wing of Luprops sinensis Marseul ( $8.5 \mathrm{~mm}$. in length)

4b Met-endosternite of Luprops sinensis Marseul (1.3 mm. in length)

$4 \mathrm{c}$ Hind tarsus of Luprops sinensis Marseul (1.5 mm. in length)

$5 \mathrm{a}$ Hind wing of Heterotarsus crenulifer Kaszab (11.0 mm. in length)

$5 \mathrm{~b}$ Met-endosternite of Heterotarsus cremulifer Kaszab (1.9 mm. in length)

$5 \mathrm{c}$ Hind tarsus of Heterolarsus crenulifer Kaszab $(2.0 \mathrm{~mm}$. in length) 

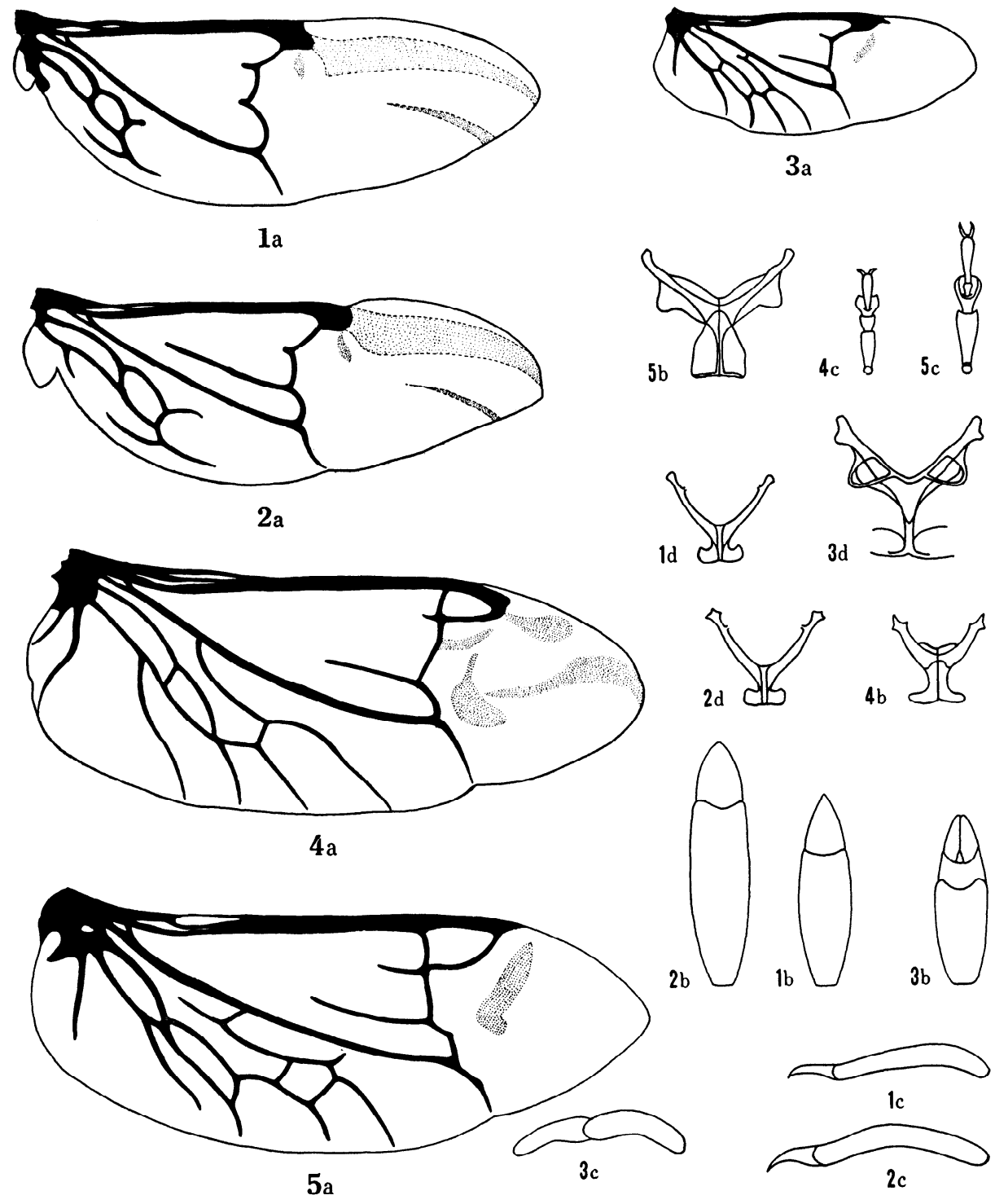

Taxonomic study on the Tenebrionidae of the Ryukyu Islands 


\section{Explanation of Plate 2}

1 Diphyrrhinchus iriomotensis sp. nov. (5.0 mm. in length)

2 Caedius minimus sp. nov. ( $3.0 \mathrm{~mm}$. in length)

3 Basanus amamiensis sp. nov. (7.0 $\mathrm{mm}$. in length)

4 Phaedis (Phaedis) magnipunclalus sp. nov. (7.5 mm. in length). 


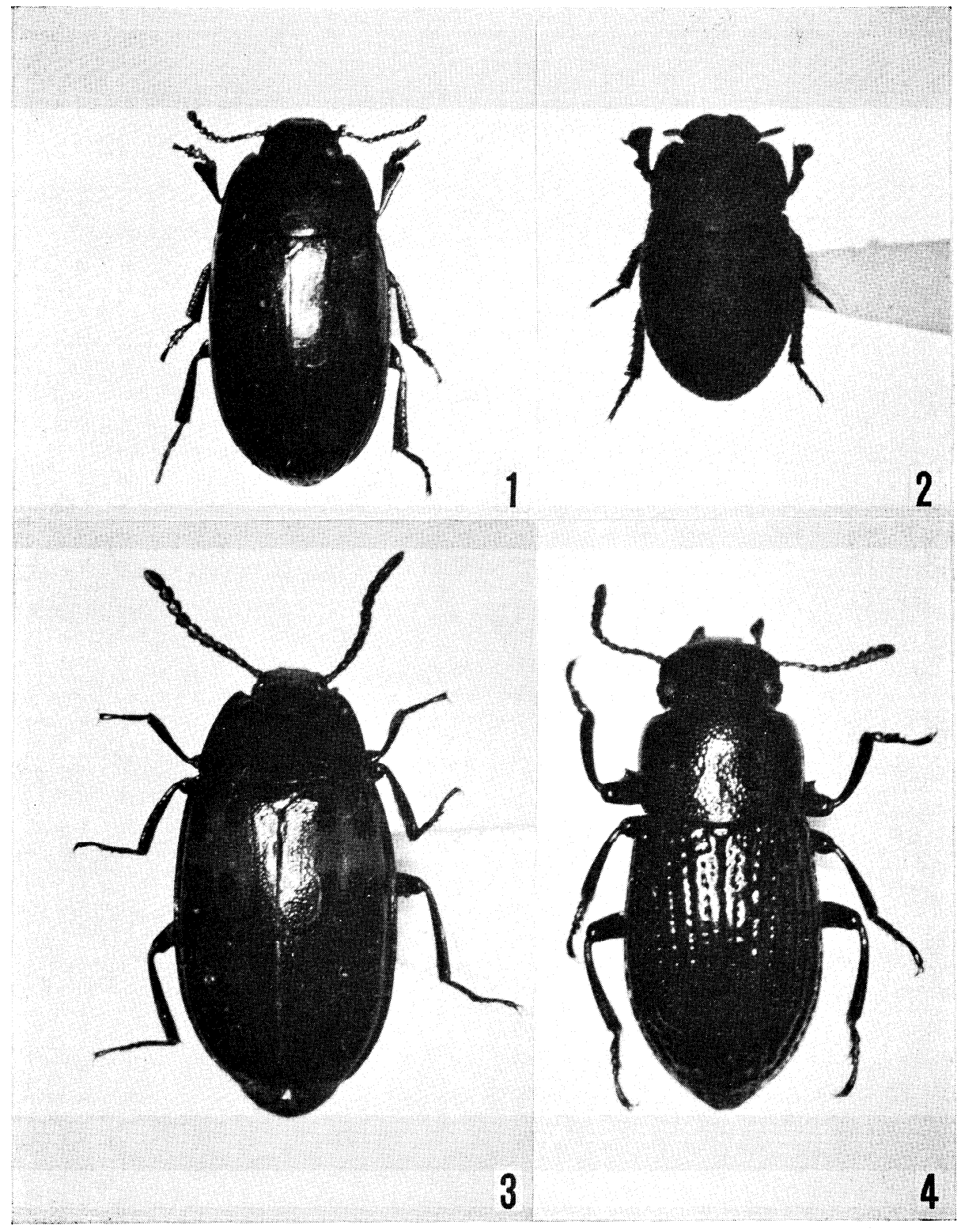

Taxonomic study on the Tenebrionidae of the Ryukyu Islands 